\title{
Quantile-Dependent Expressivity and Gene-Lifestyle Interactions Involving High-Density Lipoprotein Cholesterol
}

\author{
Paul T. Williams \\ Molecular Biophysics \& Integrated Bioimaging, Lawrence Berkeley National Laboratory, Berkeley, CA, USA
}

\section{Keywords}

High-density lipoprotein cholesterol - Gene-lifestyle interaction - Gene-environment - Body weight - Alcohol . Smoking · Physical activity · Diet · Carbohydrates

\section{Abstract \\ Background: The phenotypic expression of a high-density lipoprotein (HDL) genetic risk score has been shown to de- pend upon whether the phenotype (HDL-cholesterol) is high or low relative to its distribution in the population (quantile- dependent expressivity). This may be due to the effects of genetic mutations on HDL-metabolism being concentration dependent. Method: The purpose of this article is to assess whether some previously reported HDL gene-lifestyle inter- actions could potentially be attributable to quantile-depen- dent expressivity. Summary: Seventy-three published ex- amples of HDL gene-lifestyle interactions were interpreted from the perspective of quantile-dependent expressivity. These included interactive effects of diet, alcohol, physical activity, adiposity, and smoking with genetic variants associ- ated with the $A B C A 1, A D H 3, A N G P T L 4, A P O A 1, A P O A 4, A P O A 5$, APOC3, APOE, CETP, CLASP1, CYP7A1, GALNT2, LDLR, LHX1, LIPC, LIPG, LPL, MVK-MMAB, PLTP, PON1, PPARa, SIRT1, SNTA1,}

and UCP1 genes. The selected examples showed larger genetic effect sizes for lifestyle conditions associated with higher vis-à-vis lower average HDL-cholesterol concentrations. This suggests these reported interactions could be the result of selecting subjects for conditions that differentiate high from low HDL-cholesterol (e.g., lean vs. overweight, active vs. sedentary, high-fat vs. high-carbohydrate diets, alcohol drinkers vs. abstainers, nonsmokers vs. smokers) producing larger versus smaller genetic effect sizes. Key Message: Quantile-dependent expressivity provides a potential explanation for some reported gene-lifestyle interactions for HDLcholesterol. Although overall genetic heritability appears to be quantile specific, this may vary by genetic variant and environmental exposure.

(c) 2020 The Author(s)

Published by S. Karger AG, Basel

\section{Introduction}

High-density lipoprotein (HDL) cholesterol is associated with lower coronary heart disease and stroke risk [1]. Weight, physical activity, diet, alcohol intake, and smoking are all lifestyle factors affecting HDL-cholesterol concentrations [1]. Individual responses vary substantially,

$\begin{array}{ll}\text { karger@karger.com } & \text { (c) } 2020 \text { The Author(s) } \\ \text { www.karger.com/lfg } & \text { Published by S. Karger AG, Basel } \\ & \text { This article is licensed under the Creative Commons Attribution- } \\ \text { Karger } & \begin{array}{l}\text { NonCommercial-NoDerivatives 4.0 International License (CC BY- } \\ \text { NC-ND) (http://www.karger.com/Services/OpenAccessLicense). } \\ \text { Usage and distribution for commercial purposes as well as any dis- } \\ \text { tribution of modified material requires written permission. }\end{array}\end{array}$

Paul T. Williams

Molecular Biophysics \& Integrated Bioimaging

Lawrence Berkeley National Laboratory, 1 Cyclotron Road

Berkeley, CA 94720 (USA)

ptwilliams@lbl.gov 


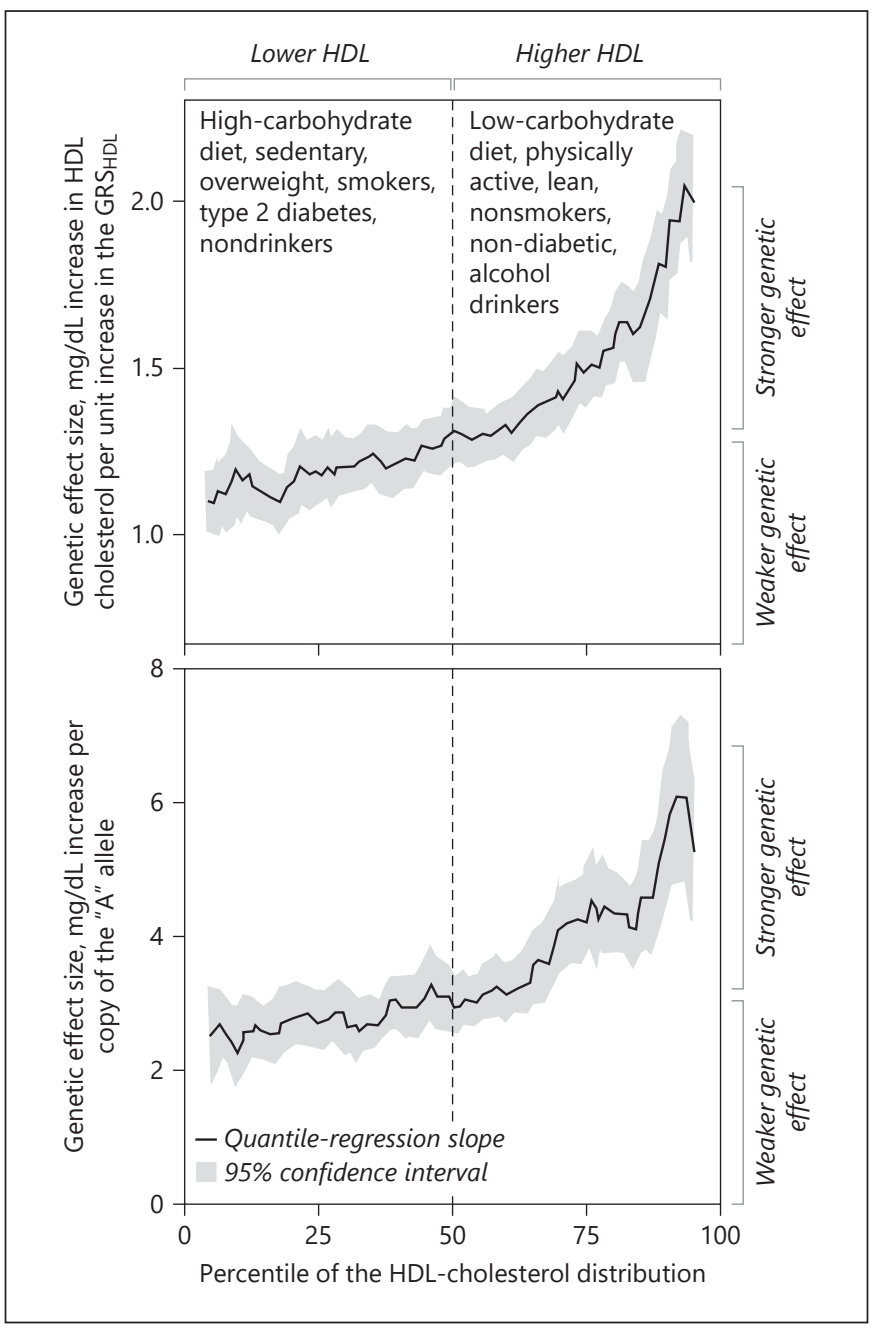

Fig. 1. Gene-environment interaction due to sample selection. Effects of a 47-SNP genetic risk score $\left(\mathrm{GRS}_{\mathrm{HDL}}\right)$ and cholesterol ester transfer protein (CETP) rs3764261 polymorphism on plasma HDL-cholesterol concentrations by quantiles of the HDL-cholesterol distribution [3], showing that sampling by characteristics associated with high HDL-cholesterol concentrations (low carbohydrate diet, alcohol consumption, physically active lifestyle, leanness, nonsmokers) will show a larger genetic effect size than characteristics associated with low HDL-cholesterol concentrations, i.e. an apparent gene-environment interaction.

which may be due, in part, to genetic differences. Such gene-lifestyle interactions can be characterized as genetic effects (e.g., HDL differences among genotypes) that differ by environment, or environmental effects (e.g., HDLBMI relationship) that differ by genotype. HDL-cholesterol is among the most commonly reported cardiometabolic phenotypes exhibiting gene-environment interactions [2].
Quantile-dependent expressivity postulates that the phenotypic expression of a genetic variant may be dependent upon whether the phenotype (e.g., HDL-cholesterol) is high or low relative to its distribution [3-10]. For example, Figure 1 shows that the effect size of a 47-SNP genetic risk score $\left(\mathrm{GRS}_{\mathrm{HDL}}\right)$ increases with the percentile of the HDL-cholesterol distribution [3]. Compared to the $\mathrm{GRS}_{\mathrm{HDL}}$ 's phenotypic effect at the 10th population percentile, its effect size was 1.9-fold greater at the 90th percentile of the HDL-cholesterol distribution. Figure 1 also shows that the effect size of the cholesterol ester transfer protein $(C E T P)$ rs3764261 risk allele was 2.4-fold greater at the 90th than 10th HDL-cholesterol percentile. Elsewhere, we have shown that HDL-cholesterol heritability $\left(h^{2}\right)$, estimated from the offspring-parent regression slope, increased significantly $\left(p=4.2 \times 10^{-5}\right)$ from the 10th $\left(h^{2} \pm\right.$ SE: $\left.0.44 \pm 0.03\right), 25$ th $(0.45 \pm 0.03), 50$ th $(0.47$ $\pm 0.03), 75$ th $(0.56 \pm 0.04)$, to the 90 th percentiles $(0.65 \pm$ 0.06 ) of the offspring's age- and sex-adjusted HDL-cholesterol distribution [10].

One consequence of quantile-dependent expressivity is that sampling on the basis of environmental factors that distinguish high versus low portions of the HDL-cholesterol distribution will yield different estimates of the genetic effect size, as illustrated in Figure 1. For example, from the traditional perspective of gene-environment interaction, the histogram of Figure 2a shows a greater HDL-cholesterol difference between cyclist and sedentary men for AA homozygotes of the LIPC $-250 \mathrm{G}>\mathrm{A}$ (rs2070895) polymorphism than carriers of the $G$ allele [11]. Alternatively, the line graph in Figure 2a shows that the cyclist had higher average HDL-cholesterol than the sedentary men, and in accordance with quantile-dependent expressivity (Fig. 1), the difference between genotypes (i.e., effect size) was greater because of the cyclists' higher HDL-cholesterol.

Similarly, purported predictors of drug or diet efficacy may simply be genetic markers that trace the increase in heritability at higher HDL-cholesterol concentrations [7, 10]. For example, the histogram in Figure $2 \mathrm{~b}$ shows that fenofibrate produced greater increases in HDL-cholesterol for T-allele carriers than GG homozygotes of the $\mathrm{m} 204 \mathrm{~T}>\mathrm{G} 7 \mathrm{a}$-hydroxylase (CYP7A1) polymorphism in the study by Shen et al. [12]. Alternatively, there was a larger genetic effect size when average HDL-cholesterol was increased following treatment vis-à-vis the lower pretreated HDL-cholesterol. The difference between the preand post-treatment genetic effect size means the effects of the genotypes cannot move in parallel when HDL-choles- 
terol is pharmacologically increased (Figure $2 \mathrm{~b}$ line graph). In this case, subtracting pre-treatment from the post-treatment HDL-cholesterol levels will necessarily create a relatively greater HDL-cholesterol increase for the carriers of the T-allele.

This paper uses previously published reports on geneenvironment interactions for two specific aims: firstly, to provide evidence for quantile-dependent expressivity through examples of environmental factors that affect HDL-cholesterol concentrations and change genetic effect size in accordance with Figure 1 (i.e., external validity); secondly, to assess whether 73 selected examples of gene-environment interactions might be more simply explained by quantile-dependent expressivity, as has been suggested for gene-environment interactions of other traits: adiposity, pulmonary function, coffee and alcohol intake, triglyceride concentrations, and postprandial lipemia [3-10]. These examples extend our previous analyses of HDL-cholesterol pharmacogenetic and nutrigenetic markers [10] to a variety of gene-lifestyle interactions, i.e. alcohol consumption, body weight, physical activity, smoking, and diet. To the best of our knowledge, quantile effects have heretofore been largely unrecognized in pharmacogenetics and genetic epidemiology.

\section{Methods}

The objective was to identify examples of gene-environment interactions affecting HDL-cholesterol concentrations that are potentially the consequence of quantile-dependent expressivity and the selection of subjects by characteristics that distinguish high from low HDL-cholesterol. For several reasons, a rigorous metaanalysis or formal systematic review of HDL gene-environment interactions was not attempted. Specifically, except for a few papers published by us, quantile-dependent expressivity has not been previously assessed. In addition: (1) there is no standard protocol for reporting gene-environment interactions; (2) nonsignificant gene-environment interactions are rarely reported, whilst significant interactions are seldom replicated [2]; (3) unadjusted genotype by environment HDL values are often unavailable because it is desirable to adjust the observations for age, sex, and other confounders to eliminate their potential impact. Moreover, pooling across studies is problematic because quantile-dependent expressivity probably varies by genetic variant and environmental condition, and except for CETP rs3764261 [3], remains to be determined for individual SNPs.

The initial source of studies was the catalogue of gene-environment interactions assembled by Parnell et al [2]. In addition, abstracts were retrieved from a National Institutes of Health (NIH) National Library of Medicine (https://pubmed.ncbi.nlm.nih.gov) search of the terms "high density lipoprotein" or "HDL"; "genetics" and "gene," and "interaction" and "modify," and read for whether they were likely to report significant gene-environment interactions. References cited within each retrieved article were

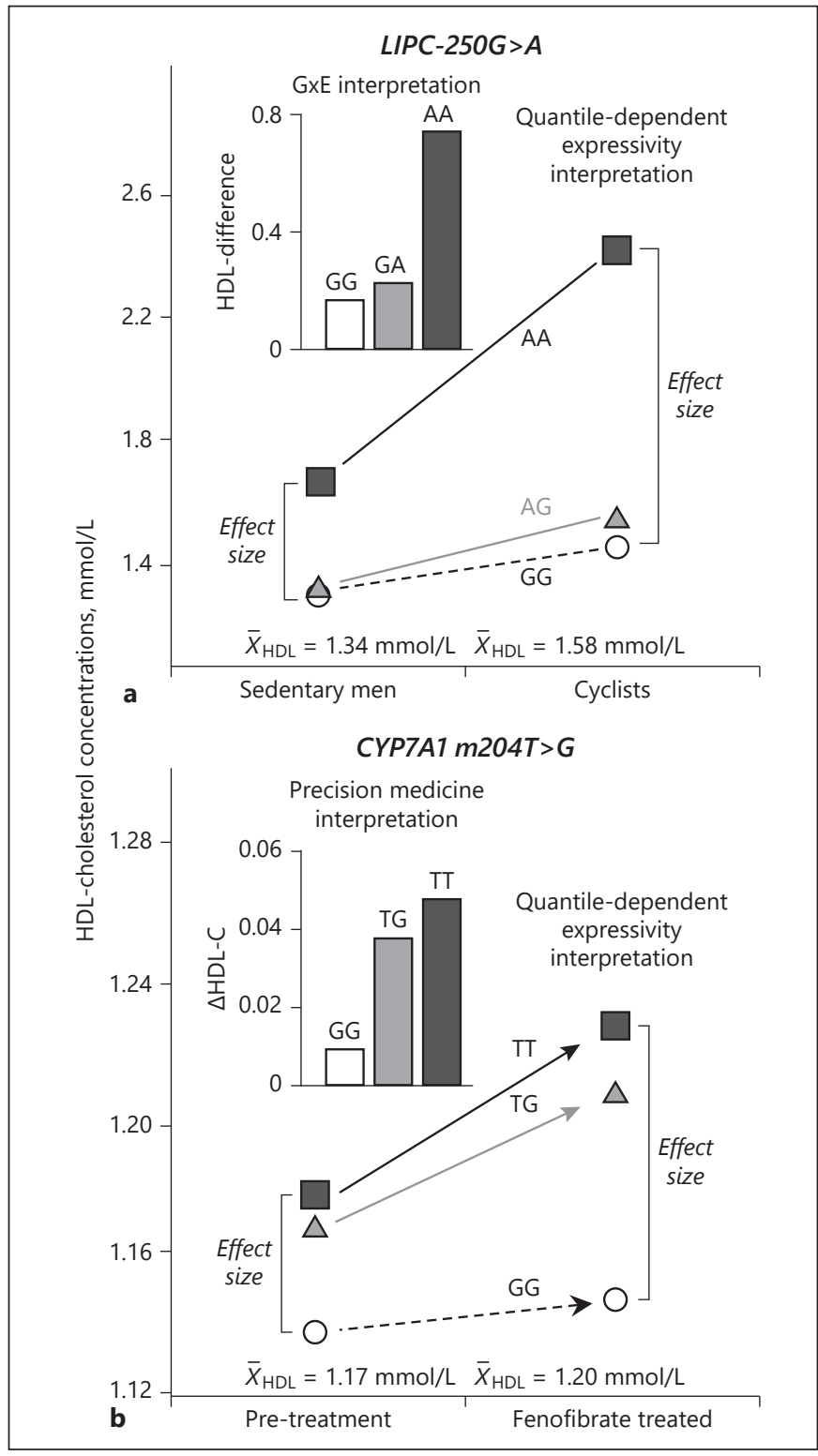

Fig. 2. Precision medicine vs. quantile-dependent expressivity. a The histogram compares the mean differences in HDL-cholesterol between cyclist and sedentary men by LIPC -250G > A (rs2070895) promoter genotypes as reported by Pisciotta et al. [11], suggesting that AA homozygotes showed the greatest exercise benefit (a precision medicine interpretation). Alternatively, the line graph attributes the difference between genotypes to the larger genetic effect size in the cyclist due to their higher average HDL-cholesterol (a quantile-dependent expressivity interpretation). b The histogram compares the fenofibrate-induced HDL-cholesterol increases between cholesterol 7a-hydroxylase (CYP7A1) m204T>G genotypes as reported by Shen et al. [12], suggesting that TT and TG genotypes had the greatest HDL-cholesterol benefit (a precision medicine perspective, $p=0.01$ ). Alternatively, the line graph attributes the genotype difference to the larger genetic effect size after treatment than before, due to average HDL-cholesterol being higher when treated (a quantile-dependent expressivity interpretation). 


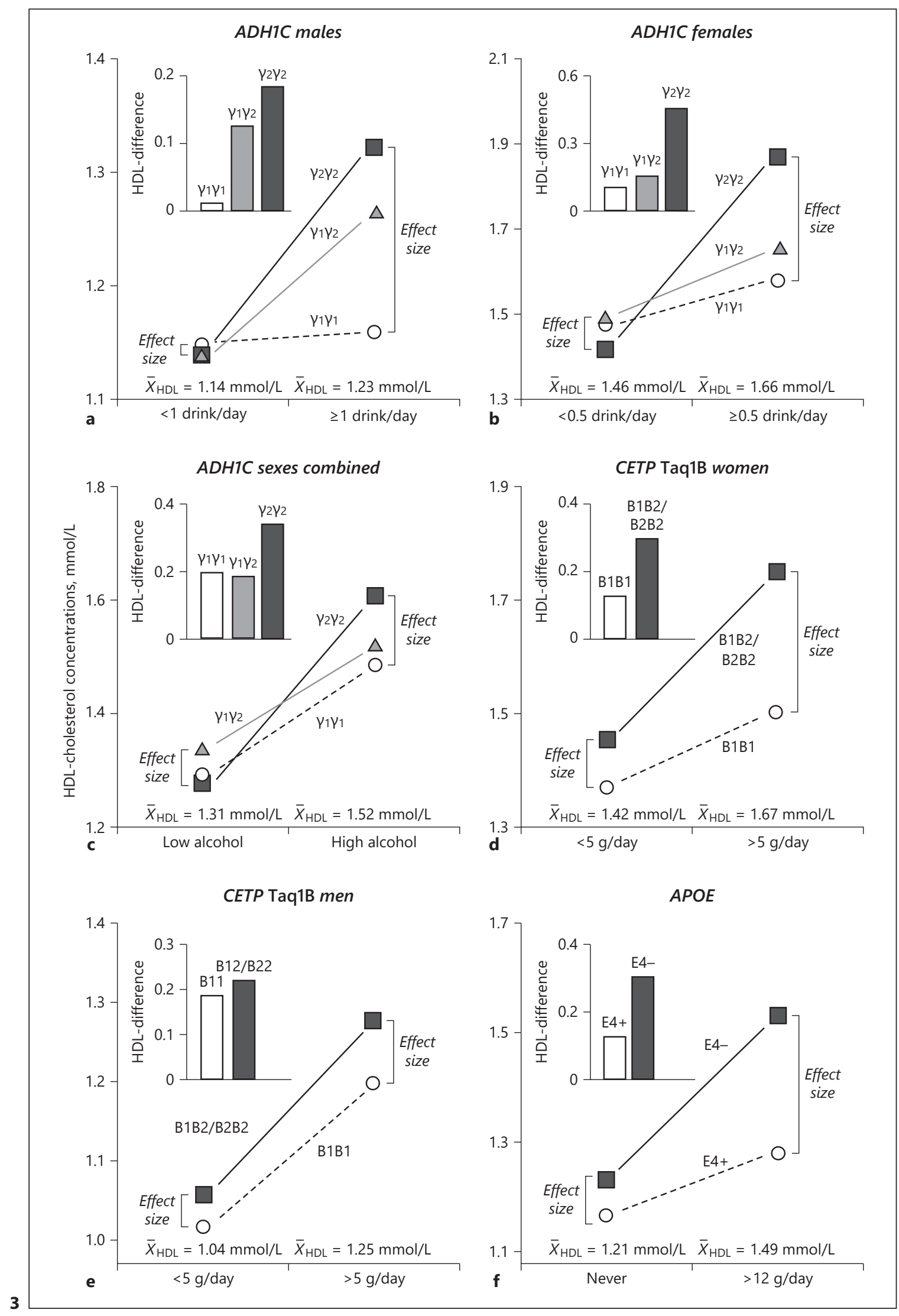

(For legend see next page.) 
also examined as sources for gene-environment interactions. Promising articles were evaluated for whether they included the information required to assess quantile-dependent expressivity, ideally, the unadjusted genotype-specific HDL-cholesterol concentrations at each environmental condition, or text descriptions consistent with quantile-dependent expressivity. Examples were selected that represented fan-shaped interactions that occur when the impact of the gene on the phenotype differs by environmental stratum [13], or the impact of the environment on the phenotype differs by genotype. Crossover gene-environment interactions showing opposite genetic effects for different environmental conditions or opposite environmental effects for different genotypes could be real, but they are not consistent with quantile-dependent expressivity and were not included.

In some cases, gene-environment interactions were originally reported as histograms or line graphs that were imported into $\mathrm{Mi}$ crosoft PowerPoint (version 12.3.6 for Macintosh computers, Microsoft corporation, Redmond, WA, USA) to extract their quantitative information as previously described [8]. In this report, HDLcholesterol results are generally reported as means or slopes \pm SE in Système International units $(38.61 \mathrm{mg} / \mathrm{dL}=1 \mathrm{mmol} / \mathrm{L})$. Online supplementary Table 1 (see www.karger.com/doi/10.1159/000511421 for all online suppl. material) describes the studies cited in this report. HDL-cholesterol responses to drug and diet interventions that were reviewed previously [10] are not repeated in this report.

\section{Results and Discussion}

\section{Alcohol}

Meta-analyses by Hata and Nakajima [14] suggest that $\mathrm{HDL}$-cholesterol increases an average of $0.06 \mathrm{mmol} / \mathrm{L} \mathrm{per}$ $23 \mathrm{~g} /$ day of alcohol consumed, equivalent to 1 large beer. The increase has been attributed to enhanced hepatic and extra-hepatic HDL production, decreased HDL-cholesterol removal, and decreased CETP concentration and activity [15]. Alcohol also increases rates of cholesterol esterification [16] and apoA1 and apoAII transport [17]. The majority of the gene-alcohol interactions reported to date shows that alcohol increases HDL-cholesterol while accentuating genetic effects on HDL-cholesterol, consistent with the quantile-dependent expressivity.

Fig. 3. Precision medicine interpretation of genotype-specific effects of alcohol intake on HDL-cholesterol (histograms) vs. their quantile-dependent expressivity interpretation (line graphs, i.e. showing larger genetic effect size when average HDL-cholesterol concentrations were high). a The 2001 report by Hines et al. [18] on men consuming more vs. less than one drink/day by fast homodimeric $\gamma_{1} \gamma_{1}$ homozygotes, $\gamma_{1} \gamma_{2}$ heterozygotes, and slow homodimeric $\gamma_{2} \gamma_{2}$ homozygotes of the alcohol dehydrogenase type $1 \mathrm{C}(A D H 1 C)$ gene $\left(p_{\text {interaction }}=0.05\right)$; $\mathbf{b}$ The 2001 report by Hines et al. [18] on women consuming more vs. less than 0.5 drinks/day by $A D H 1 C$ genotypes $\left(p_{\text {interaction }}=0.02\right)$. c The 2005 report by
For example, $A D H 1 C$ is one of the class I alcohol dehydrogenase isoenzymes that oxidize ethanol [18]. There is a 2.5-fold difference in the maximal velocity of ethanol oxidation between the fast homodimeric $\gamma_{1}$ and the slow homodimeric $\gamma_{2}$ isoenzyme. The slower rate of alcohol clearance in $\gamma_{2}$ carriers may accentuate its effect on HDLcholesterol in men (Fig. 3a histogram) and women (Fig. 3b histogram). Hines et al. [18] reported that HDLcholesterol was highest in $\gamma_{2}$ homozygotes, intermediate in heterozygotes, and least in $\gamma_{1}$ homozygotes if they averaged $\geq 1$ drinks/day ( $\left.p_{\text {trend }}=0.007\right)$ but not if they averaged $<1$ drinks/day ( $\left.p_{\text {interaction }}=0.05\right)$, and in women if they averaged $\geq 0.5$ but not $<0.5$ drinks $/$ day $\left(p_{\text {interaction }}=\right.$ 0.02 ). The accompanying line graphs of Figures $3 a$ and $b$ show these results are consistent with quantile-dependent expressivity given that the genetic effect size was greater for the higher average HDL-cholesterol concentration above than below one drink/day in men (average HDL-cholesterol 1.23 vs. $1.14 \mathrm{mmol} / \mathrm{L}$ ) and above than below 0.5 drinks/day in women (1.66 vs. $1.46 \mathrm{mmol} / \mathrm{L}$ ). A second report in men and non-hormone using postmenopausal women by Hines et al. [19] found a 0.137 $\mathrm{mmol} / \mathrm{L}$ HDL-cholesterol difference $(p=0.02)$ between $\gamma_{2}$ and $\gamma_{1}$ homozygotes in heavy drinkers but not in nonheavy drinkers (Fig. 3c). This second observation is also potentially attributable to quantile-dependent expressivity given the higher average HDL-cholesterol concentrations in the drinkers than abstainers (1.52 vs. 1.31 $\mathrm{mmol} / \mathrm{L}$ ).

CETP mediates cholesteryl ester-triglyceride exchange between HDL and LDL and VLDL particles and is inversely associated with HDL-cholesterol concentrations [1]. Alcohol was reported to accentuate the effects of two CETP polymorphisms on HDL-cholesterol in ECTIM study, the CETP TaqIB B2 allele affecting the 277th nucleotide in the gene's first intron $\left(p_{\text {interaction }}<0.0001\right)[20$ ], and the A allele of the $-629 \mathrm{C}>\mathrm{A}$ polymorphism in its promoter region $\left(p_{\text {interaction }}<0.002\right)[21]$. As alcohol con-

Hines et al. [19] on men and postmenopausal women consuming high vs. low alcohol intake by $A D H 1 C$ genotypes. d The 2008 report by Jensen et al. [22] on postmenopausal women consuming more vs. less than $5 \mathrm{~g}$ /day by cholesteryl ester transfer protein (CETP) Taq1B genotypes ( $\left.p_{\text {interaction }}<0.01\right)$. e The 2008 report by Jensen et al. [22] on men consuming more vs. less than $5 \mathrm{~g} /$ day by CETP Taq1B genotypes $\left(p_{\text {interaction }}<0.01\right)$. $\mathbf{f}$ The 2004 report by Djoussé et al. [25] on drinkers consuming $>12$ g/day vs. abstainers by $A P O E$ carriers vs. noncarriers of the $\varepsilon 4$-allele ( $p_{\text {interaction }}=$ $0.0006)$. 


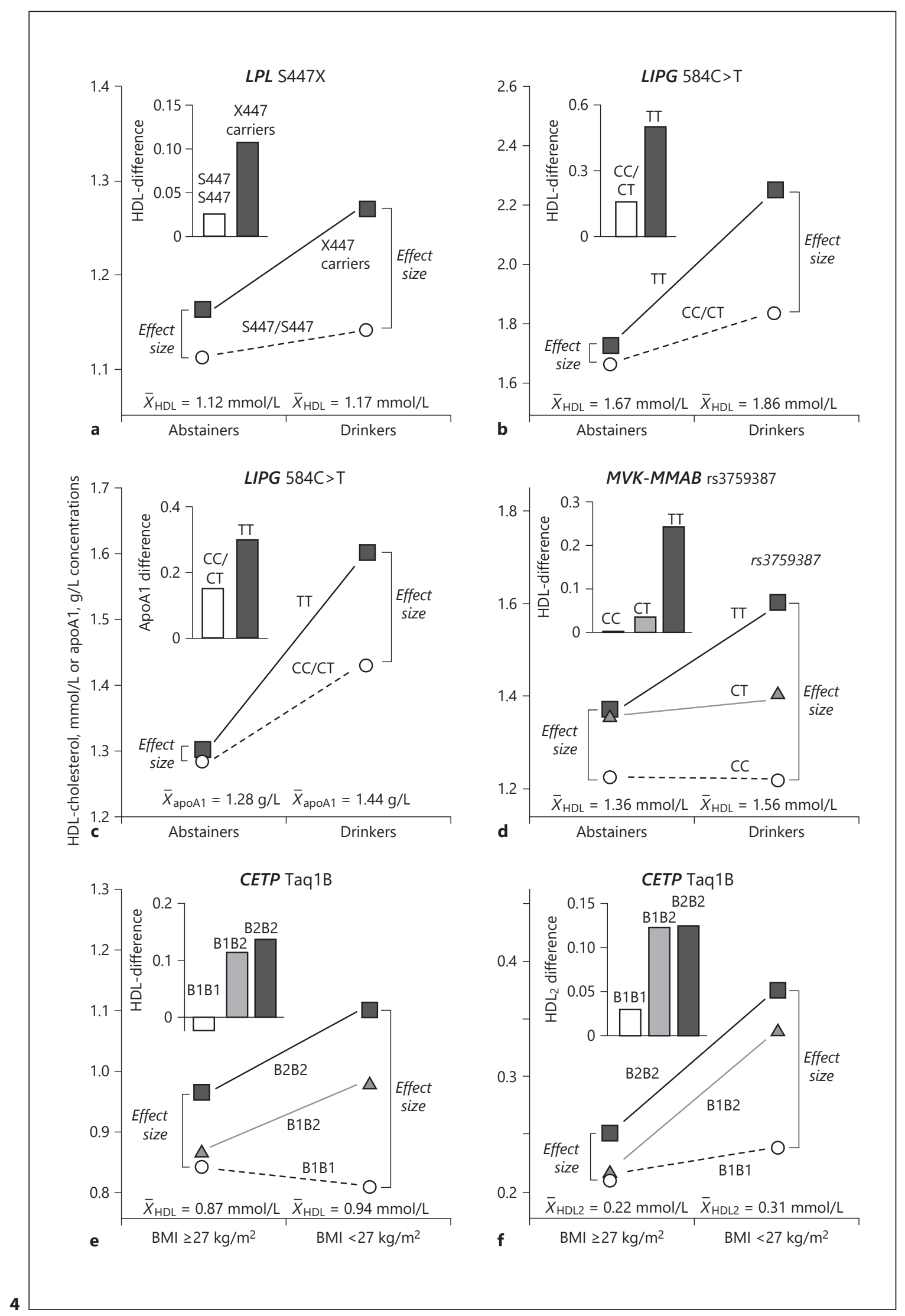

(For legend see next page.) 
sumption increased $(0,1-25,26-50,51-75,>75 \mathrm{mg} /$ day $)$, the effect per dose of the CETP/TaqIB B2 allele increased progressively from $-0.03 \mathrm{mmol} / \mathrm{L}$ (ns), $0.03 \mathrm{mmol} / \mathrm{L}$ (ns), $0.11 \mathrm{mmol} / \mathrm{L}(p<0.01), 0.15 \mathrm{mmol} / \mathrm{L}(p<0.02)$, and 0.20 $\mathrm{mmol} / \mathrm{L}(p=0.001)$, respectively. The corresponding increases per dose of the $-629 \mathrm{~A}$ allele were $-0.02,0.0,0.10$, 0.13 , and $0.16 \mathrm{mmol} / \mathrm{L}$ (estimated from their figure 4). However, average HDL-cholesterol concentrations also increased with increasing alcohol intake $(1.25 \pm 0.03,1.28$ $\pm 0.02,1.31 \pm 0.02,1.36 \pm 0.04,1.49 \pm 0.04 \mathrm{mmol} / \mathrm{L})$, suggesting quantile-dependent expressivity as a possible explanation.

Jensen et al. [22] also reported a significant gene-alcohol interaction between the CETP Taq1B variant and alcohol intake $\left(p_{\text {interaction }}<0.01\right)$ in control women of the Nurses Health Study and men of the Health Professionals Follow-up Study. For women, we estimated from their figure 1 that the HDL-cholesterol difference between B2carriers and B1B1 homozygotes was $0.25 \mathrm{mmol} / \mathrm{L}$ for $>5$ $\mathrm{g} /$ day versus $0.08 \mathrm{mmol} / \mathrm{L}$ for $<5 \mathrm{~g} /$ day alcohol intake, which corresponded to the higher average HDL-cholesterol in the heavier drinkers (1.67 vs. $1.42 \mathrm{mmol} / \mathrm{L}$, Fig. $3 d$ ). In men, the authors' figure 2 shows that the HDL-cholesterol difference between B2-carriers and $\mathrm{B} 1 \mathrm{~B} 1$ homozygotes was $0.08 \mathrm{mmol} / \mathrm{L}$ for $>5 \mathrm{~g} /$ day versus $0.04 \mathrm{mmol} / \mathrm{L}$ for $<5 \mathrm{~g} /$ day, which again corresponded to the higher average HDL-cholesterol in the heavier drinkers (1.25 vs. $1.04 \mathrm{mmol} / \mathrm{L}$, Fig. 3e). Quantile-dependent expressivity might also explain the larger genotype differences in women than men in accordance with the women's higher average HDL-cholesterol ( $1.5 \mathrm{vs.} 1.1 \mathrm{mmol} / \mathrm{L}$ ).

A third study by Tsujita et al. [23] also reported significant interactions between the CETP Taq1B variant and alcohol intake in men $\left(p_{\text {interaction }}=0.05\right)$ and women $\left(p_{\text {interaction }}=0.02\right)$, showing a larger genetic effect in association with the higher overall HDL-cholesterol concentration in the heavier drinkers. In men, the difference between B2 carriers and B1B1 homozygotes was $0.084 \pm$ $0.040 \mathrm{mmol} / \mathrm{L}$ for $\geq 2$ drinks/day versus $-0.019 \pm 0.035$ $\mathrm{mmol} / \mathrm{L}$ for $<2$ drinks/day, whilst average HDL-cholesterol was higher for $\geq 2(1.42 \pm 0.02 \mathrm{mmol} / \mathrm{L})$ versus $<2$

Fig. 4. Precision medicine interpretation of genotype-specific effects of alcohol and adiposity (histograms) vs. their quantile-dependent expressivity interpretation (line graphs). a The 2004 report by Lee et al. [26] on the HDL-cholesterol difference between alcohol consumers and abstainers by lipoprotein lipase $(L P L)$ S447X genotypes $\left(p_{\text {interaction }}<0.01\right)$. b The 2011 report by Liu et al. [28] on the HDL-cholesterol difference between alcohol consumers vs. abstainers by hepatic lipase (LIPG) $584 \mathrm{C}>\mathrm{T}$ genotypes drinks/day $(1.30 \pm 0.02 \mathrm{mmol} / \mathrm{L})$. In women the difference between B22 homozygotes and B1 carriers was 0.22 $\pm 0.06 \mathrm{mmol} / \mathrm{L}$ for drinkers versus $0.08 \pm 0.03 \mathrm{mmol} / \mathrm{L}$ for abstainers, whilst mean HDL-cholesterol was somewhat higher for drinkers $(1.61 \pm 0.02 \mathrm{mmol} / \mathrm{L})$ versus abstainers $(1.56 \pm 0.01 \mathrm{mmol} / \mathrm{L})$.

Gudnason et al. [24] reported that the effect of the Vallele of the CETP I405V polymorphism on Icelandic men's HDL-cholesterol and apoAI was significant only in drinkers ( $p_{\text {interaction }}<0.05$ for both variables), which quantile-dependent expressivity would attribute to the drinkers' 10.6\% higher HDL-cholesterol and 6\% higher apoAI concentrations.

Apo E may affect HDL-cholesterol by affecting plasma triglyceride and VLDL concentrations, but it is also carried on some HDL and may independently affect HDLcholesterol concentration [1]. Djoussé et al. [25] reported that the apparent increase in average HDL-cholesterol with increasing alcohol intake $(0,0.1-12 \mathrm{~g} /$ day, $>12 \mathrm{~g} /$ day) was greater in noncarriers of the $A P O E$ \&4 allele (mean \pm SE: $1.23 \pm 0.04,1.36 \pm 0.04,1.53 \pm 0.04 \mathrm{mmol} / \mathrm{L}$, respectively, $\left.p_{\text {trend }}<0.0001\right)$ than in APOE $\varepsilon 4$ carriers $(1.16 \pm 0.05,1.28 \pm 0.07,1.28 \pm 0.05 \mathrm{mmol} / \mathrm{L}$, respectively, $\left.p_{\text {trend }}=0.98\right)$. Quantile-dependent expressivity would attribute these cross-sectional differences to a larger effect size when HDL-cholesterol levels are higher due to greater alcohol intake. Specifically, Figure $3 \mathrm{f}$ shows that the HDL-cholesterol difference between $\varepsilon 4$ noncarriers and carriers was smaller for abstainers $(0.07 \pm 0.06$ $\mathrm{mmol} / \mathrm{L}, p=0.27$ ) and those consuming $0.1-12 \mathrm{~g} /$ day of alcohol $(0.08 \pm 0.08 \mathrm{mmol} / \mathrm{L}, p=0.32)$ than those who drank $>12 \mathrm{~g} /$ day $(0.25 \pm 0.07 \mathrm{mmol} / \mathrm{L}, p=0.0004)$ because average HDL-cholesterol concentrations was lower for abstainers $(1.21 \pm 0.03 \mathrm{mmol} / \mathrm{L})$, and those consuming $0.1-12 \mathrm{~g} /$ day $(1.34 \pm 0.03 \mathrm{mmol} / \mathrm{L})$, than those who drank $>12 \mathrm{~g} /$ day $(1.49 \pm 0.04 \mathrm{mmol} / \mathrm{L})$.

The S447X polymorphism produces a premature truncation of lipoprotein lipase (LPL), increases LPL secretion, and increases postheparin LPL activity, resulting in HDL-cholesterol concentrations that are $4 \%$ higher. In men, the data of Lee et al. [26] showed great-

( $\left.p_{\text {interaction }}<0.01\right)$. c The 2011 report by Lui et al. [28] on apoA1 differences $\left(p_{\text {interaction }}<0.05\right)$. d The 2017 report by Miao et al. [30] on the HDL-cholesterol difference between drinkers and abstainers by $M V K-M M A B$ rs3759387 genotypes $\left(p_{\text {interaction }}=0.001\right)$. e The 1999 report by Vohl et al. [38] on the HDL-cholesterol difference between high vs. low BMI by CETP-TaqIB genotype. $f$ The 1999 report by Vohl et al. [38] on the $\mathrm{HDL}_{2}$-cholesterol difference between high vs. low BMI by CETP-TaqIB genotypes. 


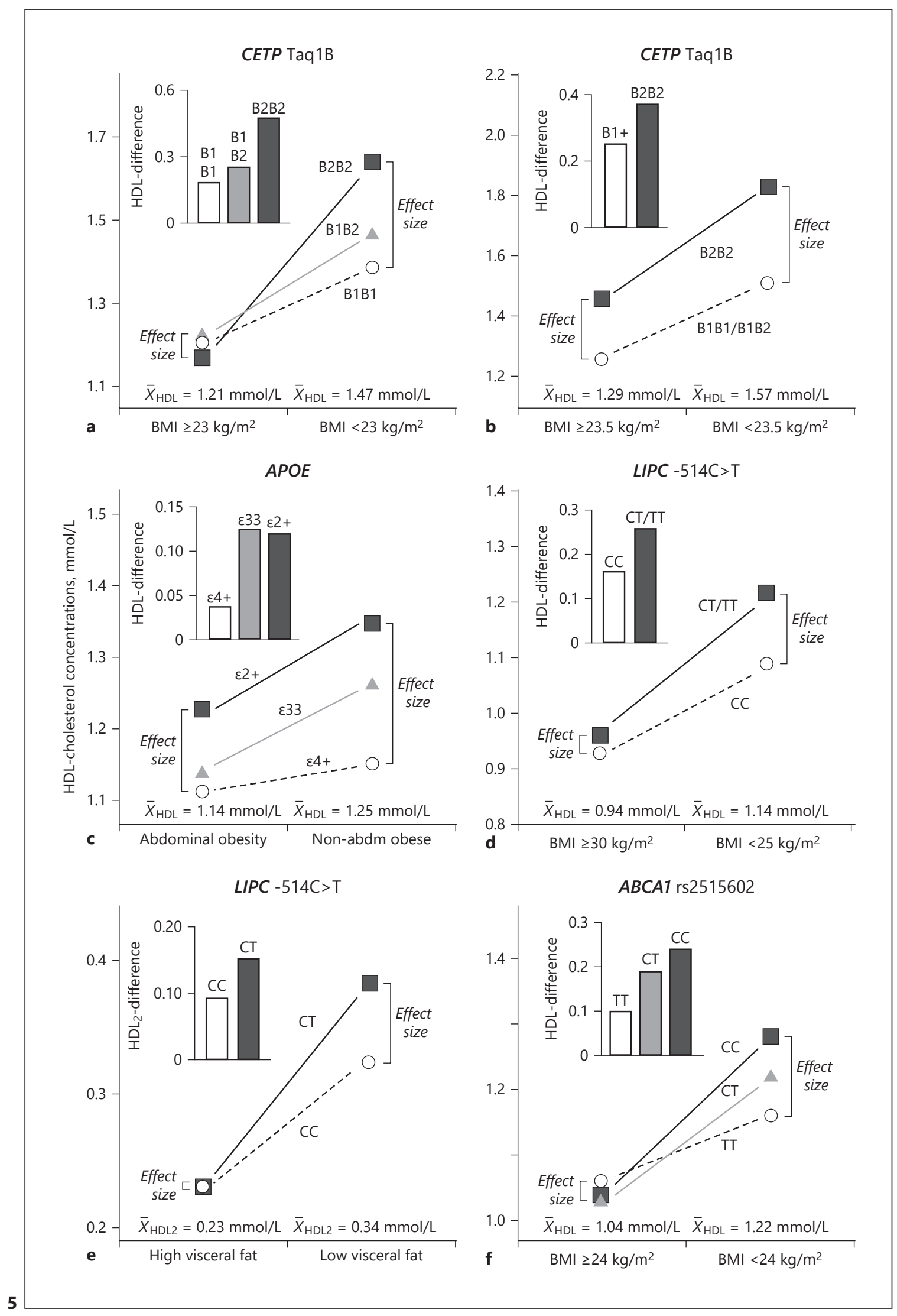


er HDL-cholesterol differences between drinkers and abstainers in carriers than noncarriers of the $\mathrm{x} 447 \mathrm{mu}$ tation $\left(0.11 \pm 0.05\right.$ vs. $0.03 \pm 0.03 \mathrm{mmol} / \mathrm{L}, p_{\text {interaction }}=$ $0.11)$. Figure $4 \mathrm{a}$ shows that this corresponded to a larger genotype difference between $\mathrm{x} 447$ carriers and noncarriers in drinkers $(0.13 \pm 0.04 \mathrm{mmol} / \mathrm{L})$ who had higher average HDL-cholesterol concentrations $(1.17 \pm 0.08$ $\mathrm{mmol} / \mathrm{L})$ than in abstainers $(0.05 \pm 0.03 \mathrm{mmol} / \mathrm{L})$ who had lower HDL-cholesterol concentrations $(1.12 \pm 0.07$ $\mathrm{mmol} / \mathrm{L})$. Women also showed a greater alcohol effect in carriers compared to noncarriers $(0.20 \pm 0.12$ vs. $\left.-0.07 \pm 0.05 \mathrm{mmol} / \mathrm{L}, p_{\text {interaction }}=0.03\right)$ and a larger difference between genotypes in drinkers $(0.33 \pm 0.13$ $\mathrm{mmol} / \mathrm{L})$ than abstainers $(0.06 \pm 0.04 \mathrm{mmol} / \mathrm{L})$, but no difference in average HDL-cholesterol concentrations by drinking status.

Baik et al. [27] reported that the HDL-cholesterol differences between LPL rs10503669 genotypes (surrogate for the S447X mutation) were greatest for drinking $>15$ $\mathrm{g} /$ day (effect size: $0.063 \mathrm{mmol} / \mathrm{L}$ ), intermediate for drinking $\leq 15 \mathrm{~g} /$ day $(0.025 \mathrm{mmol} / \mathrm{L})$, and least for abstainers $\left(0.013 \mathrm{mmol} / \mathrm{L}, p_{\text {interaction }}<0.01\right)$, and although average HDL-cholesterol concentrations were not reported, they were presumably higher in drinkers.

Liu et al. [28] reported a significant interaction between alcohol intake and the LIPG $584 \mathrm{C}>\mathrm{T}$ polymorphism for both HDL-cholesterol ( $p_{\text {interaction }}<0.01$, Fig. $4 \mathrm{~b}$ ) and apoA1 ( $p_{\text {interaction }}<0.05$, Fig. $\left.4 c\right)$. They concluded that TT homozygotes showed greater alcohol-induced increases in HDL-cholesterol and apoA1 than carriers of the $\mathrm{C}$-allele. From the perspective of quantile-dependent expressivity, the genotype difference (TT minus C-carriers) was greater in drinkers than abstainers for HDL-cholesterol $(0.405 \pm 0.118$ vs. $0.062 \pm 0.079 \mathrm{mmol} / \mathrm{L})$ and apoA1 $(0.170 \pm 0.060$ vs. $0.018 \pm 0.038 \mathrm{~g} / \mathrm{L})$ because the drinkers' had higher average HDL-cholesterol (1.856 \pm 0.022 vs. $1.670 \pm 0.016 \mathrm{mmol} / \mathrm{L})$ and higher apoA 1 concentrations $(1.439 \pm 0.014$ vs. $1.282 \pm 0.010 \mathrm{~g} / \mathrm{L})$.

Apo C-III is an inhibitor of lipoprotein lipase that is carried on triglyceride-rich lipoproteins [1]. The SstI

Fig. 5. Precision medicine interpretation of genotype-specific effects of adiposity (histograms) vs. their quantile-dependent expressivity interpretation (line graphs). a The 2011 report by Huang et al. [39] on the HDL-cholesterol difference between normal weight and overweight/obese Asians by CETP TaqIB genotypes. b The 1994 report by Freeman et al. [40] on HDL-cholesterol differences above and below $23.5 \mathrm{~kg} / \mathrm{m}^{2}$ by CETP TaqIB genotypes. c The 2012 report by Zarkesh et al. [41] on the HDL-cholesterol difference between abdominally obese and nonobese subjects by

Quantile-Dependent Expressivity of HDL-Cholesterol polymorphism (rs5128) is a $\mathrm{C}>\mathrm{G}$ substitution at nucleotide 3238 in the $3^{\prime}$ untranslated region of the gene. Ruixing et al. [29] reported that the HDL-cholesterol difference among SstI genotypes was greater in drinkers (CC/ CG/GG: $2.07,2.23,2.12 \mathrm{mmol} / \mathrm{L}, p=0.002)$ than abstainers (CC/CG/GG: $1.97,1.98,2.01 \mathrm{mmol} / \mathrm{L}, p=0.83)$, consistent with the higher average HDL-cholesterol concentrations in drinkers than abstainers $(2.14 \pm 0.02$ vs. $1.98 \pm$ $0.02 \mathrm{mmol} / \mathrm{L}$ ).

Quantile-dependent expressivity may also account for interactions involving other genes. Miao et al. [30] reported that the effect of the of mevalonate kinase ( $M V K)$ and methylmalonic aciduria cblB type $(M M A B)$ gene rs3759387 variant on HDL-cholesterol was significant in drinkers but not abstainers ( $p_{\text {interaction }} \leq 0.001$ ), which Figure $4 \mathrm{~d}$ suggests could be due to the drinkers' higher HDL-cholesterol concentrations. Volcik et al. [31] reported that HDL-cholesterol differed significantly between QQ homozygotes of the paraoxonase-1 (PON1) Q192R (rs662) polymorphism and carriers of the R-allele in heavy drinking Black men (difference: $0.39 \mathrm{mmol} / \mathrm{L}$ ) who had high average estimated HDL-cholesterol levels $(1.75 \mathrm{mmol} / \mathrm{L})$ but not in those who were moderate drinkers, light drinkers, or abstainers (estimated average HDLcholesterol of $1.42,1.32$, and $1.25 \mathrm{mmol} / \mathrm{L}$, respectively, $\left.p_{\text {interaction }}=0.02\right)$.

\section{Body Mass Index and Waist Circumference}

Meta-analyses suggest that HDL-cholesterol increases $0.009 \mathrm{mmol} / \mathrm{L}$ per $\mathrm{kg}$ of weight loss [32]. The inverse relationship between HDL-cholesterol and adiposity has been attributed to enhanced $\mathrm{HDL}_{2}$ uptake by adipocytes, increased apoA1 catabolism, increased CETP mass and activity, increased hepatic lipase activity, and cholesteryl ester-triglyceride exchange due to increased triglycerideenriched lipoprotein concentrations [33]. Quantile-dependent expressivity predicts a larger effect size in lean than overweight patients because of their higher average HDL-cholesterol. Multiple reports support this conjecture.

APOE $\varepsilon 3 \varepsilon 4 / \varepsilon 4 \varepsilon 4$ vs. other genotypes. d The 2005 report by Zhang et al. [42] on the HDL-cholesterol difference between normal weight and obese subjects by hepatic lipase $($ LIPC) $-514 \mathrm{C}>\mathrm{T}$ genotypes $\left(p_{\text {interaction }}=0.003\right)$. e The 2003 report by St-Pierre et al. [43] on the $\mathrm{HDL}_{2}$-cholesterol difference between high vs. low visceral adiposity by $L I P C-514 \mathrm{C}>\mathrm{T}$ genotype. f The 2016 report by Yao et al. [44] on the HDL-cholesterol difference between normal and overweight/obese Uyghur Chinese by ABCA1 rs2515602 genotypes. 
Two studies showed stronger associations for $\mathrm{GRS}_{\mathrm{HDL}}$ versus HDL-cholesterol in lean than obese subjects. The first by Cole et al. [34] reported a significantly greater effect size $\left(p_{\text {interaction }}=1.1 \times 10^{-3}\right)$ in lean subjects $(\mathrm{BMI} \leq 23$ $\mathrm{kg} / \mathrm{m}^{2}$, slope \pm SE: $2.347 \pm 0.209 \mathrm{mmol} / \mathrm{L}$ per unit increase, $p=3.4 \times 10^{-28}$ ) than in obese subjects (BMI $\geq 35$ $\left.\mathrm{kg} / \mathrm{m}^{2}, 1.466 \pm 0.166 \mathrm{mmol} / \mathrm{L}, p=2.5 \times 10^{-18}\right)$, and an intermediate effect size for intermediate BMI $(1.91 \pm 0.126$ $\left.\mathrm{mmol} / \mathrm{L}, p=2.2 \times 10^{-50}\right)$. They also reported that the HDL-cholesterol difference above versus below the median $\mathrm{GRS}_{\mathrm{HDL}}$ score was greater in lean (difference $\pm \mathrm{SE}$ : $\left.0.166 \pm 0.01 \mathrm{mmol} / \mathrm{L}, p=2.0 \times 10^{-14}\right)$ than overweight subjects $\left(0.108 \pm 0.02 \mathrm{mmol} / \mathrm{L}, p=2.3 \times 10^{-10}\right)$. In addition, lean subjects showed significantly greater effect sizes than overweight subjects for CETP (rs3764261, $p_{\text {interac- }}$ tion $\left.=1.1 \times 10^{-5}\right)$, GALNT2 $\left(\mathrm{rs} 4846914, p_{\text {interaction }}=3.0 \times\right.$ $\left.10^{-3}\right)$, LIPG $\left(\right.$ rs7241918, $\left.p_{\text {interaction }}=0.007\right)$, and PLTP polymorphisms $\left(\right.$ rs6065906, $\left.p_{\text {interaction }}=0.02\right)$. Although the average HDL-cholesterol levels in lean, intermediate, and obese subjects were not provided, their figure 1 suggests that the average HDL-cholesterol concentration in lean subjects was approximately $0.44 \mathrm{mmol} / \mathrm{L}$ higher than that of obese subjects. The second study, by Lamina et al. [35], showed that increasing BMI, waist circumference, and waist-to-hip ratio all significantly attenuated the linear relationship between a 46-SNP $\mathrm{GRS}_{\mathrm{HDL}}$ and HDLcholesterol in Germans. This was in the context of decreasing average HDL-cholesterol concentrations with increasing BMI $(0.028 \pm 0.002 \mathrm{mmol} / \mathrm{L}$ decrease per $\mathrm{kg} /$ $\mathrm{m}^{2}$ ), consistent with quantile-dependent expressivity.

Two intervention studies report greater HDL-cholesterol differences among genotypes after a program of weight loss than at baseline. The intensive lifestyle intervention arm of the Look AHEAD (Action for Health in Diabetes) study produced $3.25 \mathrm{~kg} / \mathrm{m}^{2}$ average weight loss after 1 year in overweight and obese individuals with T2DM [36]. The average HDL-cholesterol increase for 60 -year-old men and women was $0.021 \pm 0.007 \mathrm{mmol} / \mathrm{L}$ per dose of the CETP rs3764261 A allele $(p=0.004)$, which they characterize as a modifier of the HDL-cholesterol response to lifestyle intervention. However, average HDL-cholesterol concentrations increased from $1.13 \pm$ 0.01 to $1.22 \pm 0.01 \mathrm{mmol} / \mathrm{L}$, and quantile-dependent expressivity suggests that the observed $0.021 \mathrm{mmol} / \mathrm{L} \mathrm{HDL}-$ cholesterol increase was perhaps partially due to the larger effect size at the higher average HDL-cholesterol concentration at 1 year.

The second intervention study, by Heilbronn et al. [37], reported that the 5.4\% HDL-cholesterol increase after 12 -week weight loss for the $1 / 1$ genotype of the APOA4
360 His polymorphism was significantly greater than the $2.6 \%$ decrease in the $1 / 2$ genotype $(p=0.04)$. Alternatively, the $1 / 1$ versus $1 / 2$ difference between genotypes was greater after weight loss $(0.06 \mathrm{mmol} / \mathrm{L})$ when the average HDL-cholesterol concentration was higher $(1.16 \pm 0.02$ $\mathrm{mmol} / \mathrm{L})$ than before weight loss $(-0.02 \mathrm{mmol} / \mathrm{L})$ when the average was lower $(1.11 \pm 0.02 \mathrm{mmol} / \mathrm{L})$.

Cross-sectionally, 4 studies report greater HDL-raising effects of the CETP-TaqIB B2 allele in leaner than heavier subjects that correspond to the leaner subjects' higher average HDL-cholesterol. Vohl et al. [38] reported a significantly stronger effect $\left(p_{\text {interaction }}=0.01\right)$ of the gene for $\mathrm{BMI}<27 \mathrm{~kg} / \mathrm{m}^{2}$ (estimated HDL-cholesterol for B1B1/B1B2/B2B2: 0.80, 0.98, $1.10 \mathrm{mmol} / \mathrm{L}$, respectively) versus $\geq 27 \mathrm{~kg} / \mathrm{m}^{2}(0.84,0.86,0.96 \mathrm{mmol} / \mathrm{L}$, respectively), corresponding to the higher average HDL-cholesterol concentrations in leaner than heavier men ( 0.94 vs. 0.87 $\mathrm{mmol} / \mathrm{L}$, Fig. 4e). The interaction was particularly evident for $\mathrm{HDL}_{2}$-cholesterol for BMI <27 (estimated: 0.24, 0.34, $0.37 \mathrm{mmol} / \mathrm{L}$, respectively) versus heavier men (estimated: $0.21,0.22,0.25 \mathrm{mmol} / \mathrm{L}$, respectively) in accordance with the leaner men's higher average $\mathrm{HDL}_{2}$-cholesterol (0.31 vs. $0.22 \mathrm{mmol} / \mathrm{L}$, Fig. $4 \mathrm{~F}$ ).

Huang et al. [39] reported a significant difference between B1B1 versus B2B2 homozygotes $(p<0.05)$ for BMI $<23 \mathrm{~kg} / \mathrm{m}^{2}$ (B1B1: $1.39 \pm 0.07$; B1B2: $1.47 \pm 0.05$; B2B2: $1.64 \pm 0.12 \mathrm{mmol} / \mathrm{L})$ but not $\mathrm{BMI} \geq 23 \mathrm{~kg} / \mathrm{m}^{2}(1.21 \pm 0.04$; $1.22 \pm 0.03 ; 1.17 \pm 0.06 \mathrm{mmol} / \mathrm{L}$, respectively), consistent with the higher HDL-cholesterol in the lean subjects ( 1.47 \pm 0.04 vs. $1.21 \pm 0.02 \mathrm{mmol} / \mathrm{L}$, Fig. 5a). Data reported by Freeman et al. [40] showed that the HDL-cholesterol difference between B22 homozygotes and B1 carriers of the CETP Taq1B polymorphism was largest in the lowest BMI tertile $(0.42 \pm 0.18 \mathrm{mmol} / \mathrm{L})$, intermediate in the intermediate BMI tertile $(0.23 \pm 0.12 \mathrm{mmol} / \mathrm{L})$, and least in the highest BMI tertile $(0.19 \pm 0.10 \mathrm{mmol} / \mathrm{L})$. This corresponds with the average HDL-cholesterol concentrations being highest in the lowest tertile $(1.62 \pm 0.05 \mathrm{mmol} / \mathrm{L})$, intermediate in the intermediate tertile $(1.52 \pm 0.05$ $\mathrm{mmol} / \mathrm{L})$, and lowest in the highest BMI tertile (1.29 \pm $0.03 \mathrm{mmol} / \mathrm{L}$ ). Figure $5 \mathrm{~b}$ presents their results for the first and second tertiles pooled.

Data presented by Zarkesh et al. [41] showed $\varepsilon 3 \varepsilon 4 / \varepsilon 4 \varepsilon 4$ genotypes had a significantly smaller HDL-cholesterol advantage from not being abdominally obese than other $A P O E$ genotypes $\left(p_{\text {interaction }}=0.05\right.$, calculated from their table 3; Fig. 5c). Consistent with quantile-dependent expressivity, the HDL-cholesterol difference between $A P O E$ genotypes was significant in the lean $(p<0.05)$ but not the abdominally obese subjects in accordance with the higher 
average HDL-cholesterol in those who were lean (1.25 \pm 0.02 vs. $1.14 \pm 0.01 \mathrm{mmol} / \mathrm{L})$.

Hepatic lipase hydrolyzes HDL-triglycerides, mediates HDL-cholesterol uptake to the liver plasma membrane, and serves as a ligand that facilitates the hepatic binding and uptake of HDL [1]. Zhang et al. [42] reported that BMI modified the effect of the $-514 \mathrm{C}>\mathrm{T}$ polymorphism of the hepatic lipase gene (LIPC) on HDL-cholesterol $\left(p_{\text {interaction }}=0.003\right)$, i.e. the difference between Tcarriers and CC homozygotes was $0.127 \pm 0.057 \mathrm{mmol} / \mathrm{L}$ for $\mathrm{BMI} \leq 25,0.057 \pm 0.032 \mathrm{mmol} / \mathrm{L}$ for $25 \leq \mathrm{BMI}<30$, and $0.028 \pm 0.037 \mathrm{mmol} / \mathrm{L}$ for $\mathrm{BMI} \geq 30$, corresponding to the declining average HDL-cholesterol from $\mathrm{BMI} \leq 25$, (1.14 $\pm 0.03 \mathrm{mmol} / \mathrm{L}), 25 \leq \mathrm{BMI}<30(1.00 \pm 0.02 \mathrm{mmol} / \mathrm{L})$, to $\mathrm{BMI} \geq 30(0.94 \pm 0.02 \mathrm{mmol} / \mathrm{L}$, Fig. $5 \mathrm{~d})$. St-Pierre et al. [43] showed that $\mathrm{HDL}_{2}$-cholesterol concentrations differed significantly between T-carriers and CC homozygotes in men with low visceral adipose tissue ( 0.38 vs. 0.32 $\mathrm{mmol} / \mathrm{L}$ ) but not those with high visceral adipose tissue ( 0.23 vs. $0.23 \mathrm{mmol} / \mathrm{L})$ consistent with the higher $\mathrm{HDL}_{2}{ }^{-}$ cholesterol of the leaner men $(0.34$ vs. $0.23 \mathrm{mmol} / \mathrm{L}$, Fig. 5e).

$A B C A 1$ encodes the ATP-binding cassette transporter A1 protein that facilitates lipid transfer to lipid-poor apoA1 particles. Data presented by Yao et al. [44] showed that the rs2515602, rs2275542, and rs4149313 polymorphisms showed significant HDL-cholesterol differences between genotypes $(p<0.05)$ in the normal weight but not overweight and obese Uyghur Chinese, in accordance with quantile-dependent expressivity and the lower average HDL-cholesterol of the overweight/obese subjects (Fig. 5f, 6a, b).

Miao et al. [30] reported that the $M V K-M M A B$ rs7134594 variant was associated with HDL-cholesterol in Chinese Han with BMI $<24 \mathrm{~kg} / \mathrm{m}^{2}$ but not heavier Han $\left(p_{\text {interaction }}=0.001\right)$, corresponding to higher HDL-cholesterol of the former (Fig. 6c).

\section{Physical Activity}

Meta-analyses by Hata and Nakajima [14] suggest that HDL-cholesterol averages $0.08 \mathrm{mmol} / \mathrm{L}$ higher for those who walk $\geq 6,000$ steps/day, $0.13 \mathrm{mmol} / \mathrm{L}$ higher for those who jog or swim, and $0.26 \mathrm{mmol} / \mathrm{L}$ higher for those who exercise at $50 \%$ of $\mathrm{VO}_{2} \max$ for three 30 -min sessions per week compared to less active subjects. None of the 260 known main effect loci for HDL-cholesterol showed interactions with physical activity that attained Bonferroni significance in the meta-analysis of up to 120,979 subjects by Kilpeläinen et al. [45], suggesting these interactions may be less reliable for validating quantile-dependent ex-

Quantile-Dependent Expressivity of HDL-Cholesterol pressivity. Nevertheless, several studies report effects of physical activity that are consistent with quantile-dependent expressivity.

The Heritage study trained approximately 200 White and Black subjects on cycling ergometers for three 30 - to 50 -min sessions per week for 20 weeks at $55-75 \%$ of $\mathrm{VO}_{2}$ max, resulting in a $3.6 \%$ mean increase in HDL-cholesterol. Leon et al. [46] reported that exercise-induced increases in HDL-cholesterol differed significantly by APOE genotypes in White males $(p=0.05)$ and females ( $p=0.006$ ) but not Blacks (males: $p=0.15$, females: $p=$ $0.95)$. Their data suggest larger differences between $\varepsilon 3 \varepsilon 3$ and $\varepsilon 4$-carriers after training than before in White males (genotype difference: 0.103 vs. $0.085 \mathrm{mmol} / \mathrm{L}$ ) and females $(0.046$ vs. $0.016 \mathrm{mmol} / \mathrm{L})$, consistent with the higher average HDL-cholesterol concentrations after training than before in the males $(1.011$ vs. $0.937 \mathrm{mmol} / \mathrm{L})$ and females (1.253 vs. $1.157 \mathrm{mmol} / \mathrm{L})$. Pre- and post-training differences between $\varepsilon 3 \varepsilon 3$ and $\varepsilon 2$-carriers did not differ appreciably.

A smaller training study by Hagberg et al. [47] reported larger increases in the "-/-" than " $+/-$ and +/+" genotypes of the LPL Pvull polymorphism for HDL-cholesterol $(0.29 \pm 0.19$ vs. $0.06 \pm 0.03 \mathrm{mmol} / \mathrm{L}, p<0.05)$ and $\mathrm{HDL}_{2}$-cholesterol $(0.22 \pm 0.17$ vs. $0.00 \pm 0.03 \mathrm{mmol} / \mathrm{L}$, $p<0.05)$. Training increased average HDL-cholesterol concentrations from 0.92 to $1.02 \mathrm{mmol} / \mathrm{L}$ and $\mathrm{HDL}_{2}$-cholesterol concentrations from 0.10 to $0.13 \mathrm{mmol} / \mathrm{L}$. These results are consistent with the quantile-dependent expressivity prediction of a larger difference between genotypes at follow-up ("-/-" vs. "+/- and +/+" difference: $0.33 \mathrm{mmol} / \mathrm{L})$ than at baseline $(0.10 \mathrm{mmol} / \mathrm{L})$ for HDLcholesterol, and for $\mathrm{HDL}_{2}$-cholesterol (0.18 vs. -0.04 $\mathrm{mmol} / \mathrm{L}$ ).

Cross-sectionally, Ahmad et al. [48] reported that women who expended $>8.8$ metabolic equivalent (MET)hours per week at recreational activities and climbing stairs had higher average HDL-cholesterol than less active women (1.389 vs. $1.296 \mathrm{mmol} / \mathrm{L})$. Consistent with quantile-dependent expressivity, they also exhibited a significantly greater effect per dose of the CETP rs1532624 minor allele on HDL-cholesterol (active vs. inactive: $0.085 \pm 0.005$ vs. $0.070 \pm 0.005 \mathrm{mmol} / \mathrm{L}, p_{\text {interaction }}=$ $0.02)$ and apoA1 $(0.044 \pm 0.003$ vs. $0.034 \pm 0.003 \mathrm{~g} / \mathrm{L}$, $\left.p_{\text {interaction }}=0.02\right)$, and per dose of the minor allele of LIPC rs 1800588 on HDL-cholesterol $(0.059 \pm 0.005$ vs. $0.044 \pm$ $\left.0.05 \mathrm{mmol} / \mathrm{L}, p_{\text {interaction }}=0.04\right)$.

Two studies reported significant interactions between the LIPC -250G>A (rs2070895) promoter and physical activity with larger genotype differences in the most ac- 

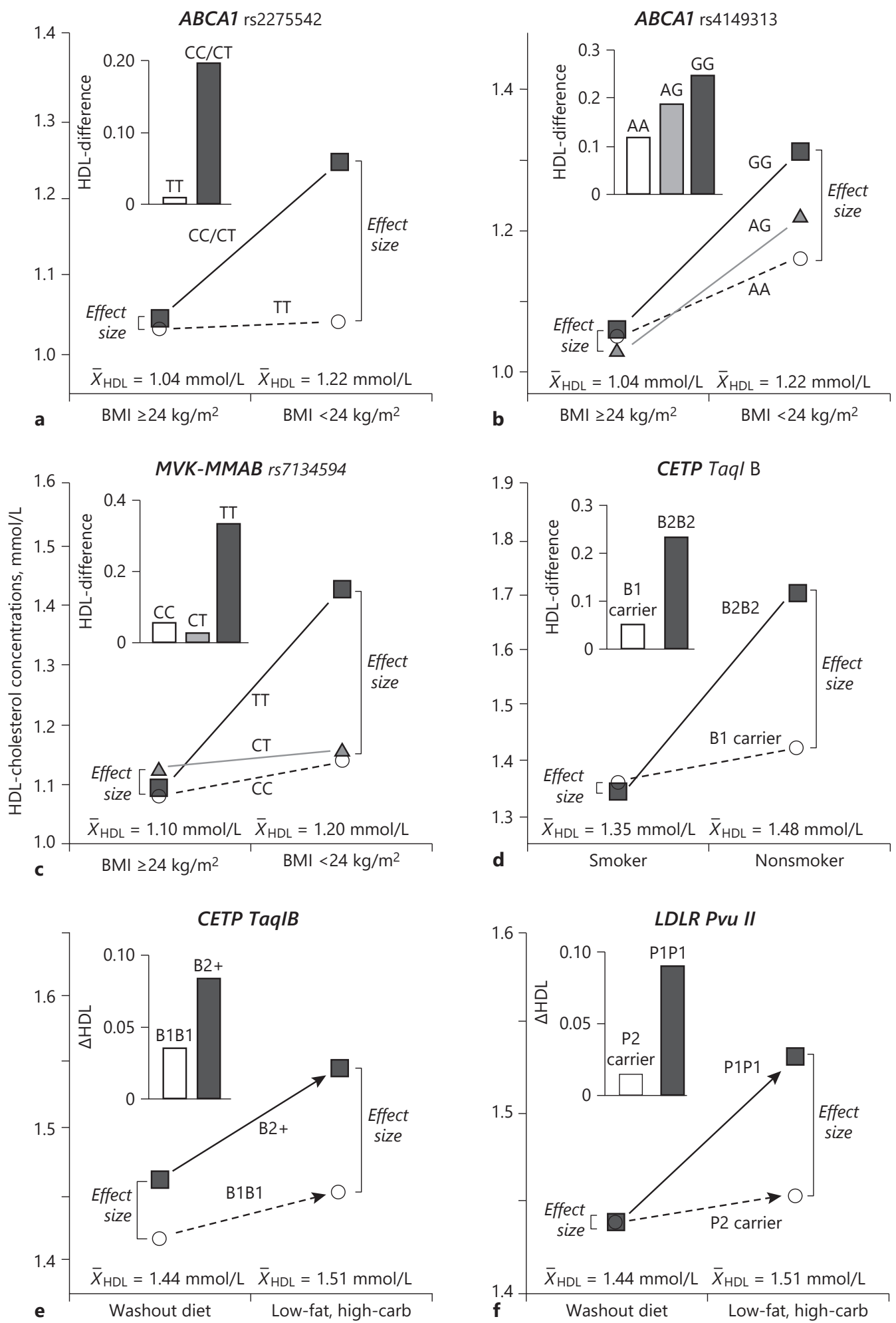

6 
tive group. This includes the report by Pisciotta et al. [11] of a greater effect on HDL-cholesterol in men who cycled $120-150 \mathrm{~km} /$ week (GG, GA, AA: 1.46, 1.54, $2.42 \mathrm{mmol} / \mathrm{L}$ ) than sedentary men $(1.29,1.30,1.66 \mathrm{mmol} / \mathrm{L}$, respectively), consistent with the higher HDL-cholesterol concentrations of the cyclist $(1.58 \pm 0.05 \mathrm{vs} .1 .34 \pm 0.03 \mathrm{mmol} / \mathrm{L}$, Fig. 2a). ApoA1 differences across genotypes were also greater in the cyclist (GG, GA, AA: 1.41, 1.47, $1.90 \mathrm{~g} / \mathrm{L}$ ) than sedentary men $(1.31,1.32,1.49 \mathrm{mmol} / \mathrm{L})$, again, consistent with the cyclists' higher average apoA 1 concentrations $(1.46 \pm 0.03$ vs. $1.32 \pm 0.02 \mathrm{mmol} / \mathrm{L})$. Grarup et al. [49] reported genotype differences that were greatest in physically active subjects, intermediate for moderately active subjects, and least in sedentary subjects $\left(p_{\text {interaction }}=0.002\right)$. They did not provide average HDLcholesterol concentrations, but presumably they were higher in those most active.

Kilpeläinen et al. [45] reported that physical activity enhanced the HDL-cholesterol-increasing effects of the CLASP1, LHX1, and SNTA1 loci from their meta-analysis, implying larger genotype differences at higher HDLcholesterol concentrations. However, these genes have not been previously associated with HDL-cholesterol.

\section{Smoking}

Meta-analyses suggest that smoker's HDL-cholesterol is on average $5.7 \%$ lower than nonsmokers and show a dose-dependent relationship from light (4.6\% lower), moderate $(6.3 \%$ lower) to heavy smokers $(8.9 \%$ lower) [50]. The lower HDL-cholesterol concentrations of smokers may reflect enhanced cholesteryl-ester triglyceride exchange due to smoking-induced increases in CETP concentrations, and increased triglyceride-enriched lipoprotein concentrations from catecholaminestimulated release of free fatty acids [51]. Whether smoking-HDL interactions provide a good test of quantile-dependent expressivity is unclear given that the multi-ethnic PAGE study found no significant evidence of genotype-smoking interactions for HDL-cholesterol in over 41,000 subjects [52]. That said, there are 6 other

Fig. 6. Precision medicine interpretation of genotype-specific effects of adiposity, smoking, and diet (histograms) vs. their quantile-dependent expressivity interpretation (line graphs). a The 2016 report by Yao et al. [44] on the HDL-cholesterol difference between normal and overweight/obese Uyghur Chinese by ABCA1 rs2275542 genotypes. b The 2016 report by Yao et al. [44] on the HDL-cholesterol difference between normal and overweight/ obese Uyghur Chinese by ATP-binding cassette transporter A1 (ABCA1) rs4149313 genotypes. c The 2017 report by Miao et al. reports whose results are consistent with the quantiledependent expressivity prediction for larger genetic effects in nonsmokers in accordance with their higher average HDL-cholesterol. A seventh study by Corella et al. [53] reported significantly higher HDL-cholesterol for the $\mathrm{H}^{-}-L P L-H i n d I I I / \varepsilon 4-A P O E$ genotype in nonsmokers $(p<0.001)$ but not smokers $(p=0.96)$ in accordance with a $0.08 \mathrm{mmol} / \mathrm{L}$ higher average $\mathrm{HDL}$-cholesterol in the nonsmokers.

Gudnason et al. [24] reported an effect of the CETP I405V polymorphism on Icelandic men's HDL-cholesterol that was significant only in nonsmokers, consistent with the 13\% higher average HDL-cholesterol in their nonsmokers than smokers. The data of Freeman et al. [40] showed an HDL-cholesterol difference between $\mathrm{B} 2 \mathrm{~B} 2$ homozygotes and B1-carriers of the CETP Taq1B polymorphism that was significantly greater in nonsmokers $(0.28 \pm 0.08 \mathrm{mmol} / \mathrm{L})$ than current smokers $(-0.02 \pm$ $0.12 \mathrm{mmol} / \mathrm{L}$, $\left.p_{\text {interaction }}=0.04\right)$, agreeing again with the nonsmokers' higher average HDL-cholesterol concentration ( $1.48 \pm 0.03$ vs. $1.35 \pm 0.04 \mathrm{mmol} / \mathrm{L}, p=0.007$, Fig. $6 \mathrm{~d}$ ). The data of Kondo et al. [54] also suggest a greater effect per dose of the $\mathrm{B} 2$ allele in nonsmokers than smokers for both HDL-cholesterol ( 0.10 vs. $0.07 \mathrm{mmol} / \mathrm{L})$ and apoA1 $(0.12$ vs. $0.03 \mathrm{~g} / \mathrm{L})$ concentrations, consistent with the nonsmokers' higher average HDL-cholesterol (1.45 \pm 0.04 vs. $1.25 \pm 0.05 \mathrm{mmol} / \mathrm{L})$ and apoA1 ( $1.50 \pm 0.03$ vs. $1.42 \pm 0.03 \mathrm{~g} / \mathrm{L})$.

From a precision medicine perspective, Lahoz et al. [55] reported that male smokers were at greater risk for low HDL-cholesterol than nonsmokers if they were Aallele carriers of the G/A polymorphism in the APOA1 promoter region (smoker vs. nonsmoker: $1.08 \pm 0.06$ vs. $1.33 \pm 0.04 \mathrm{mmol} / \mathrm{L}, p=0.006)$ but not GG homozygotes $(1.12 \pm 0.03$ vs. $1.14 \pm 0.04 \mathrm{mmol} / \mathrm{L}$, respectively, $p=$ $0.76)$. These results confirmed an earlier observation by Sigurdsson et al. [56] showing somewhat greater HDLcholesterol differences between smokers and nonsmokers in A-carriers $(-0.27 \pm 0.10 \mathrm{mmol} / \mathrm{L}, p=0.02)$ than GG homozygotes $(-0.10 \pm 0.05, p=0.03)$ in men. From the

[30] on the HDL-cholesterol difference between BMI below and above $24 \mathrm{~kg} / \mathrm{m}^{2}$ by $M V K-M M A B$ rs7134594 genotypes ( $p_{\text {interaction }}$ $=0.001)$. $\mathbf{d}$ The 1994 report by Freeman et al. [40] on HDL-cholesterol difference between smokers and nonsmokers by CETPTaqIB genotype $\left(p_{\text {interaction }}=0.04\right)$. e The 2010 report by Du et al. [63] on the HDL-cholesterol change from going onto a $15 \%$-fat 70\%-carbohydrate diet by CETP TaqIB genotypes. f The 2010 report by Du et al. [63] on the HDL-cholesterol change from going onto a $15 \%$-fat $70 \%$-carbohydrate diet by LDLR Pvu II genotypes. 
perspective of quantile-dependent expressivity, these represent larger genotype differences (A-carrier minus GG) in nonsmokers corresponding to their higher HDLcholesterol concentrations, i.e. $0.19 \pm 0.06 \mathrm{mmol} / \mathrm{L}$ genotype differences in nonsmokers versus $-0.04 \pm 0.07$ $\mathrm{mmol} / \mathrm{L}$ difference in smokers $\left(p_{\text {interaction }}=0.01\right)$ corresponding to average HDL-cholesterol concentrations of $1.22 \pm 0.03$ versus $1.10 \pm 0.03$, respectively, in Lahoz's report, and $0.14 \pm 0.08$ versus $-0.03 \pm 0.08 \mathrm{mmol} / \mathrm{L}$ genotype differences in nonsmoker and smokers, respectively, corresponding to average HDL-cholesterol concentrations of $1.21 \pm 0.03$ versus $1.06 \pm 0.03 \mathrm{mmol} / \mathrm{L}$ in Sigurdsson's report.

\section{Diet}

Meta-analyses suggest that plasma HDL-cholesterol concentrations increase $0.010 \mathrm{mmol} / \mathrm{L}$ per $1 \%$ isoenergetic replacement of carbohydrates with saturated fat, $0.008 \mathrm{mmol} / \mathrm{L}$ when substituted with monounsaturated fat, and $0.006 \mathrm{mmol} / \mathrm{L}$ when substituted with polyunsaturated fat [57]. Several gene-diet interactions were previously described that might be explained, at least in part, by larger genetic effects when HDL-cholesterol concentrations are increased by diet [10]. Additional examples follow.

Liang et al. [58] reported that HDL-cholesterol concentrations showed strong concordance to plasma eicosapentaenoic (EPA) levels in carriers of the APOE $\varepsilon 2$ allele $(\varepsilon 2+)$, moderate concordance in $\varepsilon 3 \varepsilon 3$, and an inverse relationship in carriers of the $\varepsilon 4$ allele $\left(\varepsilon 4+, p_{\text {interaction }}=\right.$ 0.0002 ). However, their figure la shows a progressively stronger relationship of the $\varepsilon 2+, \varepsilon 3 \varepsilon 3$, and $\varepsilon 4+$ ordering to HDL-cholesterol with increasing tertiles of EPA concentrations. Given the concordance between EPA and HDL-cholesterol concentrations reported by others [58], their results may be the consequence of larger APOE effects on HDL-cholesterol with increasing HDL-cholesterol concentrations.

Consistent with quantile-dependent expressivity, Inamori et al. [59] reported larger female HDL-cholesterol differences between two Sirtuin 1 (SIRT1) haplotypes when the ratio of dietary n-6/n-3 PUFA intake was low versus high for their haplotype 1 (present-absent: -0.124 \pm 0.055 difference for low ratio vs. $-0.013 \pm 0.055 \mathrm{mmol} / \mathrm{L}$ for high ratio, $p_{\text {interaction }}=0.02$ ) and haplotype 2 (presentabsent: $0.129 \pm 0.052 \mathrm{mmol} / \mathrm{L}$ difference for low ratio vs. $0.013 \pm 0.050 \mathrm{mmol} / \mathrm{L}$ difference for high ratio $\left.p_{\text {interaction }}=0.03\right)$, consistent with the higher average HDL-cholesterol concentration when the $n-6 / n-3$ ratios were lower $(1.902 \pm 0.025$ vs. $1.789 \pm 0.025 \mathrm{mmol} / \mathrm{L})$.
Riestra et al. [60] reported that T-carriers of the of LIPC C-514T polymorphism had significantly higher HDL-cholesterol concentrations than CC homozygotes only in boys consuming the top two tertiles of total, saturated, and polyunsaturated fat $(p<0.05)$, which corresponded with their having higher average HDL-cholesterol concentrations.

The loss-of-function E40K variant of the adipokine angiopoietin-like 4 (ANGPTL4) gene is thought to increase HDL-cholesterol and decrease triglycerides due to reduced inhibition of lipoprotein lipase [61]. Nettleton et al. [62] reported that the inverse cross-sectional association between men's HDL-cholesterol and carbohydrate intake was stronger in A-allele carriers than GG homozygotes (slope \pm SE: $-0.009 \pm 0.003$ vs. $-0.003 \pm 0.001$ $\mathrm{mmol} / \mathrm{L}$ per $\%$ carbohydrate, $\left.p_{\text {interaction }}=0.04\right)$. Consistent with quantile-dependent heritability, their figure 1 showed declining differences between genotypes with declining HDL-cholesterol concentrations as carbohydrate intake increased.

Du et al. [63] reported that HDL-cholesterol increased from $1.44 \pm 0.04$ to $1.51 \pm 0.04 \mathrm{mmol} / \mathrm{L}$ in Chinese Han youth who switched from a washout diet to a $15 \%$ fat and $70 \%$ carbohydrate experimental diet. HDL-cholesterol increased significantly in $\mathrm{B} 2$ carriers but not $\mathrm{B} 1 \mathrm{~B} 1$ homozygotes of the CETP TaqIB polymorphism (Fig. 6e), and in P1P1 homozygotes but not P2-carriers of the $L D L R$ $P v u$ II polymorphism (Fig. 6f) [63]. Consistent with quantile-dependent expressivity, genotype differences were greater at the higher HDL-cholesterol concentrations, i.e. larger post-treatment than pre-treatment genotype differences for CETP TaqIB (B2-carrier minus B1B1: $0.084 \pm 0.075$ vs. $0.036 \pm 0.085 \mathrm{mmol} / \mathrm{L})$ and for $L D L R$ $P v u$ II (P1P1 minus P2-carrier: $0.076 \pm 0.086$ vs. $0.001 \pm$ $0.115 \mathrm{mmol} / \mathrm{L})$.

Paradis et al. [64] reported greater HDL-cholesterol $\left(p_{\text {interaction }}=0.07\right)$ and apoA1 $\left(p_{\text {interaction }}=0.002\right)$ differences between L162 homozygotes and V162 allele carriers of the proliferator-activated receptor $(P P A R \alpha)$ Leu $162 \mathrm{Val}$ polymorphism on a high P:S diet than low P:S diet, consistent with higher average HDL-cholesterol and apoA1 concentration for the high P:S diet (Fig. 7a).

Hamada et al. [65] reported that obese women who were AA-homozygotes of the uncoupling protein-1 (UCP1) -3826 A/G polymorphism showed greater reductions in HDL-cholesterol than carriers of the G-allele when placed on a low-calorie diet $(-0.26 \pm 0.14$ vs. $-0.06 \pm 0.03 \mathrm{mmol} / \mathrm{L}, p=0.04)$. The line graph of Figure $7 \mathrm{~b}$ suggests that the genotype-specific response may simply reflect the smaller cross-sectional geno- 
type differences for the smaller post-diet average HDLcholesterol concentrations vis-à-vis the regular baseline diet.

Finally, several cross-sectional reports show larger genotype differences for higher fat diets, which are expected to correspond to higher HDL-cholesterol concentrations but where the unadjusted average HDL-cholesterol by fat intake was not provided. These include the report by Ayyappa et al. [66] of higher HDL-cholesterol concentrations in T-carriers than CC homozygotes of the $L P L$ rs1121923 polymorphism ( $p_{\text {interaction }}=0.003$ ) on high-fat but not low-fat diets, the data of Baik et al. [27] suggesting a greater effect of the X447 mutation of the LPL S447X polymorphism on HDL-cholesterol at the highest $(0.041 \mathrm{mmol} / \mathrm{L})$ and second highest quartiles of unsaturated fat intake $(0.044 \mathrm{mmol} / \mathrm{L})$, and less for the third $(0.011 \mathrm{mmol} / \mathrm{L})$ and lowest quartiles of intake $(0.008$ $\left.\mathrm{mmol} / \mathrm{L}, p_{\text {interaction }}<0.05\right)$, and the report by Li et al. [67] of a linear increase in HDL-cholesterol concentrations per dose of the B2 allele of the CETP TaqIB polymorphism for high fat intake $(p<0.001)$ but not low-fat intake $\left(p_{\text {interaction }}=0.003\right)$.

\section{Insulin Resistance and T2DM}

Lower HDL-cholesterol in T2DM is thought to be due to insulin resistance, the effects of ATP-binding cassette transporter A1 on both HDL and insulin secretion, or secondary to the effects of increased adiposity or reduced physical activity or both [68]. The significant interaction $\left(p_{\text {interaction }}=0.03\right)$ between the CETP-TaqIB polymorphism (B1B1, B1B2, B2B2) and HDL-cholesterol between men with a fasting insulin $<90.8 \mathrm{pmol} / \mathrm{L}$ (estimated: $0.80,0.91,1.01 \mathrm{mmol} / \mathrm{L}$, respectively) vs. $\geq 90.8$ $\mathrm{pmol} / \mathrm{L}(0.84,0.83,0.92 \mathrm{mmol} / \mathrm{L}$, respectively) reported by Vohl et al. [38] may be due in part to the higher average HDL-cholesterol concentrations in the men with lower insulin $(0.89$ vs. $0.85 \mathrm{mmol} / \mathrm{L})$. The interaction was particularly evident for genotype differences in $\mathrm{HDL}_{2}$-cholesterol $\left(p_{\text {interaction }}=0.03\right)$ for fasting insulin $<$ $90.8 \mathrm{pmol} / \mathrm{L}$ (estimated: $0.21,0.28,0.32 \mathrm{mmol} / \mathrm{L}$, respectively) versus $\geq 90.8 \mathrm{pmol} / \mathrm{L}$ (estimated: $0.21,0.19,0.21$ $\mathrm{mmol} / \mathrm{L}$, respectively) that we attribute to the higher $\mathrm{HDL}_{2}$-cholesterol in the men with low insulin ( 0.26 vs. $0.20 \mathrm{mmol} / \mathrm{L}$ ).

Heilbronn et al. [69] also reported that the number of B2-alleles of the CETP Taq1B polymorphism was linearly related to HDL-cholesterol concentrations in non-T2DM women below the median for fasting insulin (B1B1: 1.19 \pm 0.07 ; B1B2: $1.35 \pm 0.06$; $\mathrm{B} 2 \mathrm{~B} 2: 1.71 \pm 0.09 \mathrm{mmol} / \mathrm{L} ; p<$ $0.001)$ but not above the median $\left(p_{\text {interaction }}=0.03\right)$. Again,

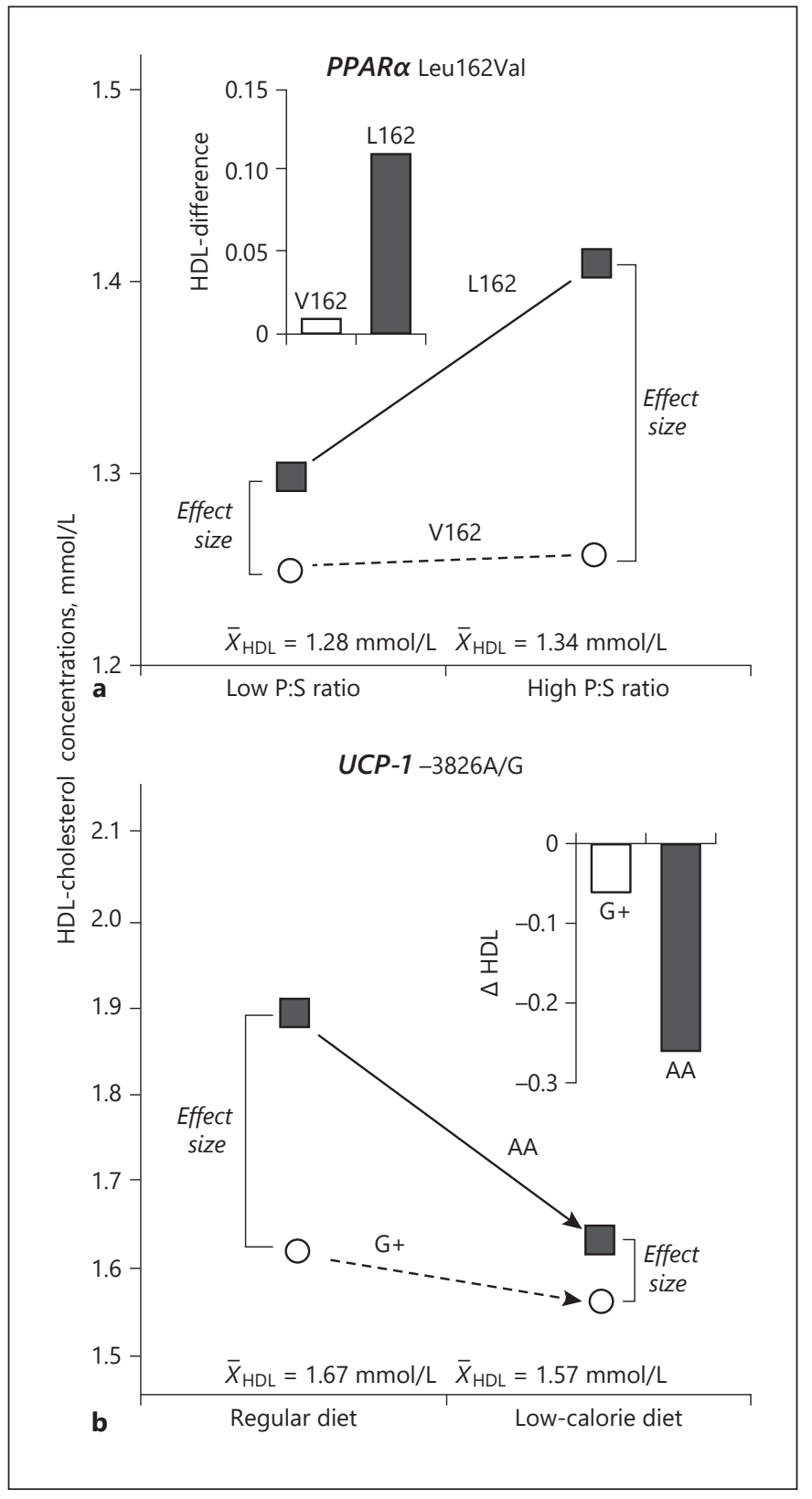

Fig. 7. Precision medicine interpretation of genotype-specific effects of diet (histograms) vs. their quantile-dependent expressivity interpretation (line graphs) for: the 2005 report by Paradis et al. [64] on the HDL-cholesterol difference between high and low polyunsaturated to saturated fatty acid (P:S) ratio diets by peroxisome proliferator-activated receptor $(P P A R \alpha)$ Leu162Val genotypes (a); the 2009 report by Hamada et al. [65] on the HDL-cholesterol change produced when switching from a basal diet to a low-calorie diet by uncoupling protein-1 (UCP1) gene -3826 A/G genotypes (b). 
quantile-dependent expressivity could contribute to the genotype-insulin interaction given that average HDLcholesterol concentrations were higher below the median insulin cutoff than above $(1.36 \pm 0.04$ vs. $1.28 \pm 0.04$ $\mathrm{mmol} / \mathrm{L})$.

\section{Exceptions}

Elsewhere, it has been shown that HDL-cholesterol heritability increases significantly with increasing average concentrations [10]. However, caution is warranted in extrapolating this result to specific SNPs given they individually account for only a very small proportion of the HDL-cholesterol genetic variance $[70,71]$. In other words, the effect of any particular SNP is not necessarily defined by quantile-dependent expressivity even if the overall genetic variance is. For example, average HDLcholesterol is lower in alcohol abstainers, smokers, physically inactive subjects, and those who consume high-carbohydrate low-fat diets. Therefore, among the significant gene-environment interactions listed in the catalogue by Parnell et al. [2], quantile-dependent expressivity would not necessarily explain the larger genetic effect size in: (1) abstainers than drinkers for the CETP TaqIB polymorphism [72]; (2) smokers than nonsmokers for the ABCG8 Thr400LysC >A polymorphism [73]; (3) lower than higher physical activity for the $L P L$ rs 10096633 polymorphism [48]; (4) higher than lower carbohydrate intake for the KCTD10_i5642G>C [74] or ATP-binding cassette transporter A1 (ABCA1) R230C polymorphisms [75]; (5) lower than higher fat intake for the APOA4 $-360 \mathrm{Gln} / \mathrm{His}$ polymorphism [76]; (6) lower than higher polyunsaturated fat intake for the IL6 $-572 \mathrm{C}>\mathrm{G}$ polymorphism [77], FA desaturase (FADS) gene cluster rs174546 [78], or FADS rs174547 polymorphisms [79]; and (7) lower than higher soy protein and soluble fiber intake for the $A B C A 1$ R230C polymorphism [80]. In addition, approximately $34 \%$ of the listed interactions lacked the information required to assess their consistency with quantile-dependent expressivity (e.g., regression slopes without intercepts, adjusted residuals), $31 \%$ presented crossover interactions (inconsistent with quantile-dependent expressivity), and 15\% were excluded for other reasons (small sample size, non-English language, and insignificant or unexpected environmental effects). Most of the interactions described in this report were identified through PubMed or cited literature, and inconsistent and excluded studies were not systematically recorded. However, some additional examples suggestive of larger genetic effect sizes at lower (not higher) average HDL-cholesterol concentrations include studies of adiposity (CETP
D442G [81], HL -514C/T and -250G/A [82], ABCA1 G378C [83], CETP TaqIB [84]), physical activity (LPL D9N [85], LIPG i24582 [86]), smoking (LPL X447 [26], CETP TaqIB [84], and diet (APOC3 -482C $>\mathrm{T}$ [87]).

\section{Conclusion}

Quantile-dependent expressivity is a novel interpretation of HDL-cholesterol gene-environment interactions that, to the best of my knowledge, has never been proposed as their possible explanation. It refers to the environment affecting the phenotype, which in turn alters the expression of the genotype (e.g., environment $\rightarrow$ phenotype $\rightarrow$ genetics). In contrast, gene-environment interactions have traditionally been interpreted as the environment affecting genetic processes that then give rise to an altered phenotype (e.g., environment $\rightarrow$ genetics $\rightarrow$ phenotype), i.e. a genotypic susceptibility of the phenotype to environmental stimuli. Because the concept is novel, it is unsurprising that most published reports do not provide the information required to evaluate its applicability, namely unadjusted HDL-cholesterol concentrations by genotype and condition. The examples provided do not show that all gene-environment interactions are attributable to quantile-dependent expressivity; rather quantiledependent expressivity provides an alternative explanation to many gene-environment interactions that warrants consideration in their interpretation.

\section{Conflict of Interest Statement}

None to report.

\section{Funding Sources}

This research was supported by grant R21ES020700 from the National Institute of Environmental Health Sciences, and an unrestricted gift from HOKA ONE ONE. The funders had no role in the preparation of the manuscript.

\section{Author Contributions}

The author is solely responsible for all aspects of the manuscript.
16

Lifestyle Genomics 2021;14:1-19 DOI: $10.1159 / 000511421$
Williams 


\section{References}

1 National Cholesterol Education Program (NCEP) Expert Panel on Detection, Evaluation, and Treatment of High Blood Cholesterol in Adults (Adult Treatment Panel III). Third Report of the National Cholesterol Education Program (NCEP) Expert Panel on Detection, Evaluation, and Treatment of High Blood Cholesterol in Adults (Adult Treatment Panel III) final report. Circulation. 2002 Dec;106(25):3143-421.

2 Parnell LD, Blokker BA, Dashti HS, Nesbeth PD, Cooper BE, Ma Y, et al. CardioGxE, a catalog of gene-environment interactions for cardiometabolic traits. BioData Min. 2014 Oct;7(1):21.

3 Williams PT. Quantile-specific penetrance of genes affecting lipoproteins, adiposity and height. PLoS One. 2012;7(1):e28764.

4 Williams PT. Quantile-specific heritability may account for gene-environment interactions involving coffee consumption. Behav Genet. 2020 Mar;50(2):119-26.

5 Williams PT. Quantile-specific heritability of intakes of alcohol but not other macronutrients. Behav Genet. 2020 Sep;50(5):332-45.

6 Williams PT. Quantile-dependent heritability of computed tomography, dual-energy x-ray absorptiometry, anthropometric, and bioelectrical measures of adiposity. Int J Obes. 2020 Jul; 44: 2101-2112. https://doi. org/10.1038/s41366-020-0636-1

7 Williams PT. Gene-environment interactions due to quantile-specific heritability of triglyceride and VLDL concentrations. Sci Rep. 2020 Mar;10(1):4486.

8 Williams PT. Quantile-dependent expressivity of postprandial lipemia. PLoS One. 2020 Feb;15(2):e0229495.

9 Williams PT. Spirometric traits show quantile-dependent heritability, which may contribute to their gene-environment interactions with smoking and pollution. PeerJ. 2020 May;8:e9145.

10 Williams PT. Quantile-specific heritability of high-density lipoproteins with implications for precision medicine. J Clin Lipidol. 2020; 14(4):448-458. doi: https://doi.org/10.1016/j. jacl.2020.05.099

11 Pisciotta L, Cantafora A, Piana A, Masturzo P, Cerone R, Minniti G, et al. Physical activity modulates effects of some genetic polymorphisms affecting cardiovascular risk in men aged over 40 years. Nutr Metab Cardiovasc Dis. 2003 Aug; 13(4):202-10.

12 Shen J, Arnett DK, Parnell LD, Lai CQ, Straka RJ, Hopkins PN, et al. The effect of CYP7A1 polymorphisms on lipid responses to fenofibrate. J Cardiovasc Pharmacol. 2012 Mar; 59(3):254-9.

13 Dick DM, Kendler KS. The impact of geneenvironment interaction on alcohol use disorders. Alcohol Res. 2012;34(3):318-24.

14 Hata Y, Nakajima K. Life-style and serum lipids and lipoproteins. J Atheroscler Thromb. 2000;7(4):177-97.
15 Hannuksela M, Marcel YL, Kesäniemi YA, Savolainen MJ. Reduction in the concentration and activity of plasma cholesteryl ester transfer protein by alcohol. J Lipid Res. 1992 May;33(5):737-44.

16 Perret B, Ruidavets JB, Vieu C, Jaspard B, Cambou JP, Terce F, et al. Alcohol consumption is associated with enrichment of highdensity lipoprotein particles in polyunsaturated lipids and increased cholesterol esterification rate. Alcohol Clin Exp Res. 2002 Aug; 26(8):1134-40.

17 De Oliveira E Silva ER, Foster D, McGee Harper M, Seidman CE, Smith JD, Breslow JL, et al. Alcohol consumption raises HDL cholesterol levels by increasing the transport rate of apolipoproteins A-I and A-II. Circulation. 2000 Nov;102(19):2347-52.

18 Hines LM, Stampfer MJ, Ma J, Gaziano JM, Ridker PM, Hankinson SE, et al. Genetic variation in alcohol dehydrogenase and the beneficial effect of moderate alcohol consumption on myocardial infarction. N Engl J Med. 2001 Feb;344(8):549-55.

19 Hines LM, Hunter DJ, Stampfer MJ, Spiegelman D, Chu NF, Rifai N, et al. Alcohol consumption and high-density lipoprotein levels: the effect of ADH1C genotype, gender and menopausal status. Atherosclerosis. 2005 Oct; 182(2):293-300.

20 Fumeron F, Betoulle D, Luc G, Behague I, Ricard S, Poirier O, et al. Alcohol intake modulates the effect of a polymorphism of the cholesteryl ester transfer protein gene on plasma high density lipoprotein and the risk of myocardial infarction. J Clin Invest. 1995 Sep; 96(3):1664-71.

21 Corbex M, Poirier O, Fumeron F, Betoulle D, Evans A, Ruidavets JB, et al. Extensive association analysis between the CETP gene and coronary heart disease phenotypes reveals several putative functional polymorphisms and gene-environment interaction. Genet Epidemiol. 2000 Jul;19(1):64-80.

22 Jensen MK, Mukamal KJ, Overvad K, Rimm EB. Alcohol consumption, TaqIB polymorphism of cholesteryl ester transfer protein, high-density lipoprotein cholesterol, and risk of coronary heart disease in men and women. Eur Heart J. 2008 Jan;29(1):104-12.

23 Tsujita Y, Nakamura Y, Zhang Q, Tamaki S, Nozaki A, Amamoto K, et al. The association between high-density lipoprotein cholesterol level and cholesteryl ester transfer protein TaqIB gene polymorphism is influenced by alcohol drinking in a population-based sample. Atherosclerosis. 2007 Mar;191(1):199205.

24 Gudnason V, Thormar K, Humphries SE. Interaction of the cholesteryl ester transfer protein I405V polymorphism with alcohol consumption in smoking and non-smoking healthy men, and the effect on plasma HDL cholesterol and apoAI concentration. Clin Genet. 1997 Jan;51(1):15-21.
25 Djoussé L, Pankow JS, Arnett DK, Eckfeldt $\mathrm{JH}$, Myers RH, Ellison RC. Apolipoprotein E polymorphism modifies the alcohol-HDL association observed in the National Heart, Lung, and Blood Institute Family Heart Study. Am J Clin Nutr. 2004 Dec;80(6):163944.

26 Lee J, Tan CS, Chia KS, Tan CE, Chew SK, Ordovas JM, et al. The lipoprotein lipase S447X polymorphism and plasma lipids: interactions with APOE polymorphisms, smoking, and alcohol consumption. J Lipid Res. 2004 Jun;45(6):1132-9.

27 Baik I, Lee S, Kim SH, Shin C. A lipoprotein lipase gene polymorphism interacts with consumption of alcohol and unsaturated fat to modulate serum HDL-cholesterol concentrations. J Nutr. 2013 Oct;143(10):1618-25.

28 Liu WY, Yin RX, Zhang L, Wu DF, Htet Aung $\mathrm{LH}, \mathrm{Hu} \mathrm{XJ}$, et al. Interactions of the LIPG $584 \mathrm{C}[\{\mathrm{GT}\}] \mathrm{T}$ polymorphism and alcohol consumption on serum lipid levels. Alcohol. 2011 Nov;45(7):681-7.

29 Ruixing Y, Yiyang L, Meng L, Kela L, Xingjiang L, Lin Z, et al. Interactions of the apolipoprotein C-III 3238C $[\{\mathrm{GT}\}] \mathrm{G}$ polymorphism and alcohol consumption on serum triglyceride levels. Lipids Health Dis. 2010 Aug;9(1): 86.

30 Miao L, Yin RX, Huang F, Chen WX, Cao XL, $\mathrm{Wu} J Z$. The effect of MVK-MMAB variants, their haplotypes and $\mathrm{G} \times \mathrm{E}$ interactions on serum lipid levels and the risk of coronary heart disease and ischemic stroke. Oncotarget. 2017 Aug;8(42):72801-17.

31 Volcik K, Ballantyne CM, Pownall HJ, Sharrett $\mathrm{AR}$, Boerwinkle E. Interaction effects of high-density lipoprotein metabolism gene variation and alcohol consumption on coronary heart disease risk: the atherosclerosis risk in communities study. J Stud Alcohol Drugs. 2007 Jul;68(4):485-92.

32 Dattilo AM, Kris-Etherton PM. Effects of weight reduction on blood lipids and lipoproteins: a meta-analysis. Am J Clin Nutr. 1992 Aug;56(2):320-8.

33 Rashid S, Genest J. Effect of obesity on highdensity lipoprotein metabolism. Obesity (Silver Spring). 2007 Dec;15(12):2875-88.

34 Cole CB, Nikpay M, Lau P, Stewart AF, Davies RW, Wells GA, et al. Adiposity significantly modifies genetic risk for dyslipidemia. J Lipid Res. 2014 Nov;55(11):2416-22.

35 Lamina C, Forer L, Schönherr S, Kollerits B, Ried JS, Gieger C, et al. Evaluation of geneobesity interaction effects on cholesterol levels: a genetic predisposition score on HDLcholesterol is modified by obesity. Atherosclerosis. 2012 Dec;225(2):363-9. 
36 Huggins GS, Papandonatos GD, Erar B, Belalcazar LM, Brautbar A, Ballantyne C, et al.; Genetics Subgroup of the Action for Health in Diabetes (Look AHEAD) Study. Do genetic modifiers of high-density lipoprotein cholesterol and triglyceride levels also modify their response to a lifestyle intervention in the setting of obesity and type-2 diabetes mellitus?: The Action for Health in Diabetes (Look AHEAD) study. Circ Cardiovasc Genet. 2013 Aug;6(4):391-9.

37 Heilbronn LK, Noakes M, Morris AM, Kind KL, Clifton PM. 360 His polymorphism of the apolipoproteinA-IV gene and plasma lipid response to energy restricted diets in overweight subjects. Atherosclerosis. 2000 May; 150(1):187-92.

38 Vohl MC, Lamarche B, Pascot A, Leroux G, Prud'homme D, Bouchard C, et al. Contribution of the cholesteryl ester transfer protein gene TaqIB polymorphism to the reduced plasma HDL-cholesterol levels found in abdominal obese men with the features of the insulin resistance syndrome. Int J Obes Relat Metab Disord. 1999 Sep;23(9):918-25.

39 Huang Y, Wu Y, Liu R, Fan P, Zhang J, Wang $F$, et al. Differential effect of ATP binding cassette transporter A1 R219K and cholesteryl ester transfer protein TaqIB genotypes on HDL-C levels in overweight/obese and nonobese Chinese subjects. Acta Cardiol. 2011 Apr;66(2):231-7.

40 Freeman DJ, Griffin BA, Holmes AP, Lindsay GM, Gaffney D, Packard CJ, et al. Regulation of plasma HDL cholesterol and subfraction distribution by genetic and environmental factors. Associations between the TaqI B RFLP in the CETP gene and smoking and obesity. Arterioscler Thromb. 1994 Mar; 14(3):336-44.

41 Zarkesh M, Daneshpour MS, Faam B, Hedayati M, Azizi F. Is there any association of apolipoprotein $\mathrm{E}$ gene polymorphism with obesity status and lipid profiles? Tehran Lipid and Glucose Study (TLGS). Gene. 2012 Nov; 509(2):282-5.

42 Zhang C, Lopez-Ridaura R, Rimm EB, Rifai $\mathrm{N}$, Hunter DJ, Hu FB. Interactions between the $-514 \mathrm{C}-[\{\mathrm{GT}\}] \mathrm{T}$ polymorphism of the hepatic lipase gene and lifestyle factors in relation to HDL concentrations among US diabetic men. Am J Clin Nutr. 2005 Jun;81(6): 1429-35.

43 St-Pierre J, Miller-Felix I, Paradis ME, Bergeron J, Lamarche B, Després JP, et al. Visceral obesity attenuates the effect of the hepatic lipase $-514 \mathrm{C}[\{\mathrm{GT}\}] \mathrm{T}$ polymorphism on plasma HDL-cholesterol levels in French-Canadian men. Mol Genet Metab. 2003 Jan; 78(1):31-6.

44 Yao MH, He J, Ma RL, Ding YS, Guo H, Yan $\mathrm{YZ}$, et al. Association between Polymorphisms and Haplotype in the ABCAl Gene and Overweight/Obesity Patients in the Uyghur Population of China. Int J Environ Res Public Health. 2016 Feb;13(2):220.
45 Kilpeläinen TO, Bentley AR, Noordam R, Sung YJ, Schwander K, Winkler TW, et al.; Lifelines Cohort Study. Multi-ancestry study of blood lipid levels identifies four loci interacting with physical activity. Nat Commun. 2019 Jan;10(1):376.

46 Leon AS, Togashi K, Rankinen T, Després JP, Rao DC, Skinner JS, et al. Association of apolipoprotein E polymorphism with blood lipids and maximal oxygen uptake in the sedentary state and after exercise training in the HERITAGE family study. Metabolism. 2004 Jan;53(1):108-16.

47 Hagberg JM, Ferrell RE, Dengel DR, Wilund KR. Exercise training-induced blood pressure and plasma lipid improvements in hypertensives may be genotype dependent. Hypertension. 1999 Jul;34(1):18-23.

48 Ahmad T, Chasman DI, Buring JE, Lee IM, Ridker PM, Everett BM. Physical activity modifies the effect of LPL, LIPC, and CETP polymorphisms on HDL-C levels and the risk of myocardial infarction in women of European ancestry. Circ Cardiovasc Genet. 2011 Feb;4(1):74-80.

49 Grarup N, Andreasen CH, Andersen MK, Albrechtsen A, Sandbaek A, Lauritzen T, et al. The $-250 \mathrm{G}[\{\mathrm{GT}\}] \mathrm{A}$ promoter variant in hepatic lipase associates with elevated fasting serum high-density lipoprotein cholesterol modulated by interaction with physical activity in a study of 16,156 Danish subjects. J Clin Endocrinol Metab. 2008 Jun;93(6):2294-9.

50 Craig WY, Palomaki GE, Haddow JE. Cigarette smoking and serum lipid and lipoprotein concentrations: an analysis of published data. BMJ. 1989 Mar;298(6676):784-8.

51 Forey BA, Fry JS, Lee PN, Thornton AJ, Coombs KJ. The effect of quitting smoking on HDL-cholesterol - a review based on withinsubject changes. Biomark Res. 2013 Sep;1(1): 26.

52 Dumitrescu L, Carty CL, Franceschini N, Hindorff LA, Cole SA, Bůžková $\mathrm{P}$, et al. No evidence of interaction between known lipidassociated genetic variants and smoking in the multi-ethnic PAGE population. Hum Genet. 2013 Dec;132(12):1427-31.

53 Corella D, Guillén M, Sáiz C, Portolés O, Sabater A, Folch J, et al. Associations of LPL and APOC3 gene polymorphisms on plasma lipids in a Mediterranean population: interaction with tobacco smoking and the APOE locus. J Lipid Res. 2002 Mar;43(3):416-27.

54 Kondo I, Berg K, Drayna D, Lawn R. DNA polymorphism at the locus for human cholesteryl ester transfer protein (CETP) is associated with high density lipoprotein cholesterol and apolipoprotein levels. Clin Genet. 1989 Jan;35(1):49-56.

55 Lahoz C, Peña R, Mostaza JM, Jiménez J, Subirats E, Pintó X, et al.; RAP Study Group. Apo A-I promoter polymorphism influences basal HDL-cholesterol and its response to pravastatin therapy. Atherosclerosis. 2003 Jun;168(2):289-95.
56 Sigurdsson G Jr, Gudnason V, Sigurdsson G, Humphries SE. Interaction between a polymorphism of the apo A-I promoter region and smoking determines plasma levels of HDL and apo A-I. Arterioscler Thromb. 1992 Sep;12(9): 1017-22.

57 Mensink RP, Zock PL, Kester AD, Katan MB Effects of dietary fatty acids and carbohydrates on the ratio of serum total to HDL cholesterol and on serum lipids and apolipoproteins: a meta-analysis of 60 controlled trials. Am J Clin Nutr. 2003 May;77(5):1146-55.

58 Liang S, Steffen LM, Steffen BT, Guan W, Weir NL, Rich SS, et al. APOE genotype modifies the association between plasma omega-3 fatty acids and plasma lipids in the Multi-Ethnic Study of Atherosclerosis (MESA). Atherosclerosis. 2013 May;228(1):181-7.

59 Inamori T, Goda T, Kasezawa N, YamakawaKobayashi K. The combined effects of genetic variation in the SIRT1 gene and dietary intake of $n-3$ and $n-6$ polyunsaturated fatty acids on serum LDL-C and HDL-C levels: a population based study. Lipids Health Dis. 2013 Jan; 12(1):4.

60 Riestra P, López-Simón L, Ortega H, Gorgojo L, Martin-Moreno JM, Schoppen S, et al. Fat intake influences the effect of the hepatic lipase C-514T polymorphism on HDL-cholesterol levels in children. Exp Biol Med (Maywood). 2009 Jul;234(7):744-9.

61 Romeo S, Pennacchio LA, Fu Y, Boerwinkle E, Tybjaerg-Hansen A, Hobbs HH, et al. Population-based resequencing of ANGPTL4 uncovers variations that reduce triglycerides and increase HDL. Nat Genet. 2007 Apr;39(4):513-6.

62 Nettleton JA, Volcik KA, Hoogeveen RC, Boerwinkle E. Carbohydrate intake modifies associations between ANGPTL4[E40K] genotype and HDL-cholesterol concentrations in White men from the Atherosclerosis Risk in Communities (ARIC) study. Atherosclerosis. 2009 Mar;203(1):214-20.

63 Du J, Fang DZ, Lin J, Xiao LY, Zhou XD, Shigdar S, et al. TaqIB polymorphism in the CETP gene modulates the impact of $\mathrm{HC} / \mathrm{LF}$ diet on the HDL profile in healthy Chinese young adults. J Nutr Biochem. 2010 Nov;21(11):1114-9.

64 Paradis AM, Fontaine-Bisson B, Bossé Y, Robitaille J, Lemieux $S$, Jacques $\mathrm{H}$, et al. The peroxisome proliferator-activated receptor alpha Leu162Val polymorphism influences the metabolic response to a dietary intervention altering fatty acid proportions in healthy men. Am J Clin Nutr. 2005 Feb;81(2):523-30.

65 Hamada T, Kotani K, Nagai N, Tsuzaki K, Matsuoka Y, Sano Y, et al. Low-calorie dietinduced reduction in serum HDL cholesterol is ameliorated in obese women with the -3826 $\mathrm{G}$ allele in the uncoupling protein-1 gene. Tohoku J Exp Med. 2009 Dec;219(4):337-42.

66 Ayyappa KA, Shatwan I, Bodhini D, Bramwell LR, Ramya K, Sudha V, et al. High fat diet modifies the association of lipoprotein lipase gene polymorphism with high density lipoprotein cholesterol in an Asian Indian population. Nutr Metab (Lond). 2017 Jan;14(1):8. 
67 Li TY, Zhang C, Asselbergs FW, Qi L, Rimm E, Hunter DJ, et al. Interaction between dietary fat intake and the cholesterol ester transfer protein TaqIB polymorphism in relation to HDL-cholesterol concentrations among US diabetic men. Am J Clin Nutr. 2007 Nov; 86(5):1524-9.

68 Fall T, Xie W, Poon W, Yaghootkar H, Mägi R, Knowles JW, et al.; GENESIS Consortium. Using Genetic Variants to Assess the Relationship Between Circulating Lipids and Type 2 Diabetes. Diabetes. 2015 Jul;64(7):2676-84.

69 Heilbronn LK, Noakes M, Clifton PM. Association between HDL-cholesterol and the Taq1B polymorphism in the cholesterol ester transfer protein gene in obese women. Atherosclerosis. 2002 Jun;162(2):419-24.

70 Teslovich TM, Musunuru K, Smith AV, Edmondson AC, Stylianou IM, Koseki M, et al. Biological, clinical and population relevance of 95 loci for blood lipids. Nature. 2010 Aug; 466(7307):707-13.

71 Willer CJ, Schmidt EM, Sengupta S, Peloso GM, Gustafsson S, Kanoni S, et al.; Global Lipids Genetics Consortium. Discovery and refinement of loci associated with lipid levels. Nat Genet. 2013 Nov;45(11):1274-83.

72 Zhou Y, Yin R, Deng Y, Li Y, Wu J. Interactions between alcohol intake and the polymorphism of rs 708272 on serum high-density lipoprotein cholesterol levels in the Guangxi Hei Yi Zhuang population. Alcohol. 2008 Nov;42(7):583-91.

73 Junyent M, Tucker KL, Smith CE, GarciaRios A, Mattei J, Lai CQ, et al. The effects of ABCG5/G8 polymorphisms on plasma HDL cholesterol concentrations depend on smoking habit in the Boston Puerto Rican Health Study. J Lipid Res. 2009 Mar;50(3):565-73.
74 Junyent M, Parnell LD, Lai CQ, Lee YC, Smith $\mathrm{CE}$, Arnett DK, et al. Novel variants at KCTD10, MVK, and MMAB genes interact with dietary carbohydrates to modulate HDLcholesterol concentrations in the Genetics of Lipid Lowering Drugs and Diet Network Study. Am J Clin Nutr. 2009 Sep;90(3):68694.

75 Romero-Hidalgo S, Villarreal-Molina T, González-Barrios JA, Canizales-Quinteros S, Rodríguez-Arellano ME, Yañez-Velazco LB, et al. Carbohydrate intake modulates the effect of the ABCA1-R230C variant on HDL cholesterol concentrations in premenopausal women. J Nutr. 2012 Feb;142(2):278-83.

76 Jansen S, Lopez-Miranda J, Ordovas JM, Zambrana JL, Marin C, Ostos MA, et al. Effect of $360 \mathrm{His}$ mutation in apolipoprotein A-IV on plasma HDL-cholesterol response to dietary fat. J Lipid Res. 1997 Oct;38(10):19952002.

77 Zhou Q, Zhang B, Wang P, Mei F, Chen CG, Sun LN, et al. Association of interleukin-6 gene -572 C $[\{\mathrm{GTT}\}] \mathrm{G}$ polymorphism with dietary intake of n- 3 fatty acids on plasma HDLc level in Chinese male adults. Asia Pac J Clin Nutr. 2010;19(4):506-12.

78 Lu Y, Feskens EJ, Dollé ME, Imholz S, Verschuren WM, Müller M, et al. Dietary n-3 and n-6 polyunsaturated fatty acid intake interacts with FADS1 genetic variation to affect total and HDL-cholesterol concentrations in the Doetinchem Cohort Study. Am J Clin Nutr. 2010 Jul;92(1):258-65.

79 Hellstrand S, Sonestedt E, Ericson U, Gullberg B, Wirfält E, Hedblad B, et al. Intake levels of dietary long-chain PUFAs modify the association between genetic variation in FADS and LDL-C. J Lipid Res. 2012 Jun; 53(6):1183-9.

80 Guevara-Cruz M, Tovar AR, Larrieta E, Canizales-Quinteros S, Torres N. Increase in HDL-C concentration by a dietary portfolio with soy protein and soluble fiber is associated with the presence of the ABCA1R230C variant in hyperlipidemic Mexican subjects. Mol Genet Metab. 2010 Oct-Nov;101(2-3): $268-72$.
81 Ruan X, Ma L, Wang S, Lindpaintner K, Liu $\mathrm{X}$, Wang B, et al. Association of two CETP polymorphisms with HDL levels in the Chinese obese population. Obesity (Silver Spring). 2009 Dec;17(12):2196-201.

82 Ko YL, Hsu LA, Hsu KH, Ko YH, Lee YS. The interactive effects of hepatic lipase gene promoter polymorphisms with sex and obesity on high-density-lipoprotein cholesterol levels in Taiwanese-Chinese. Atherosclerosis. 2004 Jan;172(1):135-42.

83 Porchay I, Péan F, Bellili N, Royer B, Cogneau J, Chesnier MC, et al. ABCA1 single nucleotide polymorphisms on high-density lipoprotein-cholesterol and overweight: the D.E.S.I.R. study. Obesity (Silver Spring). 2006 Nov; 14(11):1874-9.

84 Hodoğlugil U, Mahley RW. Smoking and obesity make a bad problem worse: genetics and lifestyle affect high density lipoprotein levels in Turks. Anadolu Kardiyol Derg. 2006 Mar;6(1):60-7.

85 Brinkley TE, Halverstadt A, Phares DA, Ferrell RE, Prigeon RL, Hagberg JM, et al. Hepatic lipase gene $-514 \mathrm{C}[\{\mathrm{GT}\}] \mathrm{T}$ variant is associated with exercise training-induced changes in VLDL and HDL by lipoprotein lipase. J Appl Physiol (1985). 2011 Dec;111(6): 1871-6.

86 Smith CE, Arnett DK, Tsai MY, Lai CQ, Parnell LD, Shen J, et al. Physical inactivity interacts with an endothelial lipase polymorphism to modulate high density lipoprotein cholesterol in the GOLDN study. Atherosclerosis. 2009 Oct;206(2):500-4.

87 Lin J, Fang DZ, Du J, Shigdar S, Xiao LY, Zhou $\mathrm{XD}$, et al. Elevated levels of triglyceride and triglyceride-rich lipoprotein triglyceride induced by a high-carbohydrate diet is associated with polymorphisms of APOA5$1131 \mathrm{~T}[\{\mathrm{GTT}\}] \mathrm{C}$ and APOC3-482C $[\{\mathrm{GT}\}] \mathrm{T}$ in Chinese healthy young adults. Ann Nutr Metab. 2011;58(2):150-7. 